\title{
LA VOLUNTAD DE LEYENDA DE MIGUEL DE LUNA
}

Desde hace ya más de un siglo se ha venido asignando a la escurridiza figura del morisco granadino Miguel de Luna un importante papel en el desenlace del drama español de su pueblo. Intérprete de arábigo al servicio de Felipe II y de su hijo, médico y aficionado a las cosas del pasado hispano-oriental, conocemos hoy mejor su colaboración con Alonso del Castillo (probable padre político y seguro espiritual) en la desesperada aventura de las falsificaciones de Granada, a fines del siglo XVI ${ }^{1}$. No ha compartido la misma fortuna su Verdadera historia del rey don Rodrigo (1592-1600) ${ }^{2}$, cuya mendacidad continúa abrumada bajo los juicios denigrantes que mereció a José Antonio Conde, Godoy Alcántara, Menéndez Pelayo y Menéndez Pidal ${ }^{3}$. Estu-

${ }^{1}$ Principalmente debid́o a los trabajos de D. CABANELAS RoDRíguez, El morisco granadino Alonso del Castillo, Granada, 1965, y "Cartas del morisco granadino Miguel de Luna”, Miscelánea de Estudios Árabes y Hebraicos, 14/15, (1965-1966), 31-47. Sobre la probabilidad del parentesco político, El morisco, p. 231, "Cartas", p. 34..

${ }^{2}$ Su primera parte fue publicada en Granada por René Rabut en 1592. La segunda, tambiên en Granada, por Sebastián de Mena en 1600 . Se sucedieron ediciones combinadas de ambas partes desde la de Zaragoza, 1602, aquí utilizada. La obra tuvo gran fortuna extranjera, traducida al inglés en 1627, al francés en 1638 y en 1648 al italiano. Bibliografia completa en A. PALAU Y DULCET, Manual del librero hispanoamericano, Madrid, 1954, t. 7.

3 "No merece mencionarse la absurda fábula, que con título de traducción de la historia de Tárif Aben Taric publicó el Morisco Miguel de Luna, que la fingi6, manifestando su ignorancia en la materia, y su imprudente osadía literaria" (J. A. CONDE, Historia de la dominación de los árabes en España, Madrid, 1820, I, p. x). La superchería había sido denunciada ya en 1799 en las Cartas para ilustrar la historia de la España árabe por don Faustino de Borbón, según J. T. MONROE, Islam and the Arabs in Spanish scholarship, Leiden, 1970, p. 9. La crítica moderna sobre Miguel de Luna se inicia en realidad con J. Godoy Alcántara, para quien el libro, más osado que ingenioso, se aprovechó de la general ignorancia de la lengua árabe para realizar algunos comentarios de interés en torno a la cuestión morisca (Historia 
diada por este último en su obra sobre las leyendas de Rodrigo, el último godo, no puede menos de considerarla como cantidad negativa en el curso de la historiografía española y se escandaliza de la desfachatez con que su autor la dedica a Felipe II. Pero el pecado imperdonable del médico falsario consiste, sobre todo, en su extraña actitud antitradicional. "Luna no deja en su sitio nada de la antigua leyenda"", la sustrae a las directrices heredadas y descarrila para todo el siglo XVII la continuidad natural del tema de Rodrigo.

Las conclusiones de Menéndez Pidal son en este punto irrebatibles. Luna tiene precisamente a gala no depender de viejas patrañas, pues para eso dice contar con una impecable fuente histórica, el alcaide Abulcácim Tárif Abentarique, testigo de los hechos y conocedor de toda suerte de cartas y papeles de sus protagonistas, según un supuesto manuscrito escurialense terminado en la ciudad de Bucara el 763, 142 de la Hixera. El uso de dicha fuente, que ahora ofrece traducida, supone el final de todo planteamiento legendario y la aportación de "una verdad tan sepultada en esta lengua, de la cual carecían nuestras historias" Sólo la lengua arábiga permite así rescatar un decisivo pasado español de su hipoteca a un ovillo de consejas, como se remacha en el prohemio de la Segunda Parte: "Están tan confusas nuestras historias (discreto lector) que a ninguno de quantos hasta oy las han leído, han dado satisfacción de la verdad" (II, Q2r). Como respaldo "erudito" de dicha consideración, Luna delata la crasa ignorancia con que no había llegado a saberse que la reina espo-

crítica de los falsos cronicones, Madrid, 1868, pp. 8-10 y 97-102). M. Menéndez Pelayo lo considera "un libro disparatado e insulso" que "obtuvo una celebridad escandalosa" y a Luna como "un inepto falsificador" que intentó suplantar "indignamente" la tradición de Rodrigo encarnada en la obra de Pedro de Corral (Orígenes de la novela, Santander, 1943, t. 2 p. 106). Para R. Menéndez Pidal (Floresta de leyendas heroicas españolas. Rodrigo, el último godo, Madrid, 1925-1927, 3 ts.), Luna y su obra son cabeza de "una serie de grandes imposturas en que se degradó la historiografia española, a partir de fines del siglo XVI" (t. 2, p. 48).

${ }^{4}$ Floresta, t. 2, p. 51.

${ }^{5}$ La verdadera historia del rey Rodrigo, en la cual se trata la causa principal de la perdida de España, y la conquista que della hizo Miramamolin Almançor Rey que fue del Africa, y de las Arabias, y vida del Rey Iacob Almançor. Compuesta por el sabio Alcayde Abulcacim Tarif Abentarique, de nación Arabe, y natural de la Arabia Petrea. Nueuamente traduzida de la lengua Arabiga por Miguel de Luna vezino de Granada. Interprete del Rey don Phelippe nuestro señor, Çaragoça, Angelo Taunno, 1602, F. Av. Ejemplar que fue de Ticknor, en la Boston Public Library. 
sa de Rodrigo fue una renegada infanta de Arabia, o la lamentable confusión de Tárif con Abdaláziz, personajes separados por más de ciento veinticinco años ${ }^{6}$. Pero sobre todo, como subraya también Luna, la veracidad de su Abentarique no supone una simple elucidación académica, sino que viene a resolver además la dolorosa realidad de una cuenta de "honra" aún pendiente: "Sin afición dando a cada uno el valor y honra de la cual le dotó naturaleza" (I, fol. lv). Una cuestión de honor entre moros y cristianos y que en adelante no tendría ya razón alguna de ser ante el testimonio de la historia.

\section{ANTIGOTICISMO}

El artificio de Abentarique libera a Luna de elegir entre viejas tradiciones que todavía reflejaban la división entre vitizanos (aristócratas) y rodriguistas (populares) que por mucho tiempo se mantuvieron en el seno de la mozarabía y en el curso posterior de la leyenda. No hay para él cuestión de buscar aquí o allá un gran culpable, porque todo el mundo visigodo que se quintaesencia en Rodrigo queda afeado de los más negros colores. El rey no es sólo el forzador de Florinda (así llamada aquí por vez primera) y de la torre encantada de Toledo, "pensando sacar algún thesoro" (I, fol. 14r), sino que además es tirano y corruptor de su pueblo. Rodrigo éra sólo regente en la minoría del príncipe don Sancho, contra cuya vida conspiraba. Descubiertas sus asechanzas por la reina madre Anagilda, huyó con el heredero a Tánjar con ánimo de pedir ayuda a los moros, pero se les anticipó una temprana muerte acarreada por tantos pesares. Al quedar así como dueño, Rodrigo mandó derribar, temeroso, los castillos del reino y matar a sus alcaides, "por donde vino a ser castigado de Dios nuestro Señor" (I, fol. 9v). Contra el consejo de buenos prelados se soltó a los vicios carnales y legisló poligamia para los clérigos e incluso para los "populares" (II, fol. 33v), de donde se siguió en España la más increíble licencia. La crítica ${ }^{7}$ ha manifestado extrañeza por la forma como Luna, a remolque

${ }^{6}$ No es preciso insistir en lo absurdo de semejantes cronologías, que difícilmente podría tomar en serio el autor ni los lectores medianamente entendidos (aquí mismo se da la muerte de Abdaláziz como ocurrida en 743 . 744). Menéndez Pidal pierde en esto la paciencia: "Extravío de un loco o de un ebrio es también el desdoblar en dos la figura histórica de Abdaláziz" (Floresta, t. 2, p. 50).

${ }^{7}$ Ibid., t. 2, p. 51. Menéndez Pelayo, Orígenes de la novela, t. 2, p. 106. 
de la leyenda tardía de la penitencia de Rodrigo, le hace encontrarse con un pastor, pero no para encaminarle al arrepentimiento, sino sólo para cambiar cobardemente sus vestiduras reales y desaparecer después para siempre. Es obvio que el intérprete morisco no quiere darle otra alternativa que la de vil fugitivo, le niega la dignificación por el dolor y no tiene por qué ocuparse de un destino final en sí mismo "infame".

Lo decisivo de Luna no es, sin embargo, una figura elaborada a base de reunir todos los rasgos del tirano de folk-tale y del jayán de los libros de caballerías. Su verdadera y más alta finalidad no es otra que la de hundir a los godos en universal desprestigio. La misma Anagilda, a pesar de su papel de víctima, se acredita de bárbara y sanguinaria cuando manda cortar orejas y narices al pérfido consejero Ataúlfo. A pesar de que los moros consideren a don Julián agraviado "con razón" (I, fol. 13r), no deja de ser ésta una verdad "suya" a lo Machado, ni le exonera de ser un traidor rencoroso que "determina de vender a España a Miramamolín Almançor por vengar su injuria", como pregona (I, VI) una rúbrica de capítulo. La justicia "poética" sé encarga después de dar buena cuenta de toda la familia. Florinda, "en verse deshonrada y sin esperanza de tener estado", se encerró en una torre $\mathrm{y}$, tras proclamarse ante sus padres "la más mala muger que uvo en el mundo" (I, fol. 44r), se arrojó de ella en lamentable plagio de Melibea. Su madre cae amortecida, don Julián, lleno de remordimientos, pierde el juicio y un día se da de puñaladas, mientras que "la Condesa su muger enfermó de un cáncer incurable que le dio en el vientre" (I, fol. 44v) y murió entre grandes dolores. Si se dirige la vista a otra parte, el arzobispo don Orpas, deudo de don Rodrigo y jefe supremo de su ejército, lo traiciona en el momento decisivo, reniega de la fe cristiana y termina miserablemente, a manos de los primeros reconquistadores.

Lejos de tejer una conseja, o aun de escribir una mala novela, Luna está alzándose aquí a cuerpo limpio contra el mito neogótico, consagrado como verdad oficial española desde los tiempos de Lucas de Túy y del arzobispo Ximénez de Rada ${ }^{8}$. Salyo por detalles de su poco afortunada cosecha, el embrollo de vicios, traiciones y crímenes le viene dado por una vetusta herencia,

${ }^{8}$ J. A. Maravall, El concepto de España en la Edad Media, Madrid, 1954, pp. 336-341. Para la cuestión, todavía no bien conocida, de la polémica goticista en la literatura de la época, C. CLAVERÍA, "Reflejos del goticismo español en la fraseología del Siglo de Oro", Studia Philologica. Homenaje a Dámaso Alonso, Madrid, 1960, t. 1, 357-372; "Notas generales sobre los godos y su proyección histórica", $\mathrm{CuH}$, 1973, núms. 280/282. 541-556. 
que manipula conforme a finalidades polémicas de peso muy superior a cualquier otra consideración de orden literario. La originalidad del morisco radica en engarzarlos sin la endecha por el triste destino de los godos que imponían las crónicas medievales y también sin dar paso a las concesiones de adorno y prestigio caballesco inventadas, sobre todo, por la Crónica sarracina (1430) de Pedro de Corral ${ }^{9}$. Luna dibuja el pasado gótico como una pesadilla a la que viene a poner fin una providencial invasión musulmana. A pesar de su parentesco con el rey desaparecido, el mismo don Pelayo menciona a Rodrigo como un maleficio que aún proyecta su sombra sobre los primeros reconquistadores, "al qual Dios perdona sus grandes peccados, los cuales creo fueron causa de su destruyción, y desuentura mía" (I, fol. 40r). No hubo, pues, tal "destruición" de España, sino la de una monarquía indigna y corruptora. La Verdadera historia se esfuerza en demostrar, contra el núcleo de la tesis neogótica, que España sobrevivió casi intacta lo mismo en lo material que en lo humano y que entre ambos pueblos (unas veces en el campo de batalla y otras en el lecho conyugal) se supo hallar, de todas formas, una alternativa superior y más digna que la ofrecida por la monarquía de Rodrigo, tomado en cuanto godo quintaesencial. España (es decir, moros y cristianos) encuentra su camino por encima de una diferencia religiosa vivida como puro accidente.

La actitud de Luna representa así el mentís del intelectual morisco al neogoticismó en cuanto gran mito conservador y socialmente agresivo en la España de la época. Siendo además de tener en cuenta la oportunidad de hacerlo en 1589 (fecha de redacción muy conspicuamente aducida por la Primera Parte), justo al hilo del tomo tercero de la Crónica general de España de Ambrosio de Morales, publicado en 1587. El beato historiador cordobés, hombre de la confianza del monarca y arquetipo del ideal "felipista" en las Letras, renovaba vigorosamente al Tudense y al Toledano en su historia de la España visigoda, enaltecida en su poderío y llorada después en términos que dan perfecta razón del opuesto enjuiciamiento de Luna:

${ }^{9}$ Estudiada por Menéndez Pelayo (Orígenes de la novela, t. 2, pp. 90 y ss.) y Menéndez Pidal (Floresta, t. 1, pp. 107-121). Para la influencia y uso de la Sarracina en la obra de Ginés Pérez de Hita, véase G. GIRot, "La maurophilie littéraire en Espagne au XVI siècle", $B H i, 43$ (1941), p. 267. Mejor encuadrada por M. S. CARRASCO URGOITI, The Moorish novel, Boston, 1976, p. 94. Ediciones, en J. SIMÓN DÍAZ, Bibliografía de la literatura hispánica, Madrid, 1965, t. 3, vol. 2, 5383-5393. 
Asi cayo y fue abatida en un punto aquella soberana gloria de los Godos ensalçada por tantos siglos de continuas victorias, y estendida por toda la Europa con grandeza de señorio. Inclytos desde su principio, temidos por sus proezas, amados en su largueza, obedecidos en su gouierno, y estimados por los mas altos principes de la tierra por su valor y braueza. No quedo agora sino un triste exemplo de perdicion y desuentura tan dolorosa, que aun hasta agora pone espanto quando se oye ${ }^{10}$.

Se vive una pleamar de goticismo. Ambrosio de Morales esfumaba las últimas páginas de su crónica en un largo poema latino en ditirambo de San Hermenegildo, no en vano devoción favorita de Felipe II, por cuyos diligentes oficios con Roma se aprobaba en 1586 su fiesta litúrgica para toda España ${ }^{11}$.

Se pisa el terreno de una contienda reconocible, característica del momento y que aún dista de ser bien conocida. Por lo pronto, no se halló tan solitario Miguel de Luna en su quijotesca empresa. La disconformidad antigoticista late también en la Profecía del Tajo $^{12}$ de fray Luis de León, donde el puente estilístico de "toda la

${ }^{10}$ Crónica general de España, Alcalá de Hénares, Juan Yñiguez de Lequerica, 1587, III, fol. 293r. "El naciente nacionalismo de los reinos cristianos comenzaba a considerar como pueblos extraños a los mismos peninsulares que no compartían su catolicidad. Sólo la guerra, nunca la inteligencia ni la convivencia, podía liberar a España. . La Iglesia crẹaba el falso mito de los 'godos' (hoy hubiéramos dicho de los europeos) frente a la realidad decadente de los semitas (hoy hubiéramos puesto los africanos)" (I. DE LAS CAGIGAS, Los mudéjares, Madrid, 1949, t. 2, p. 358).

"J. M. DEL ESTAL, "Culto de Felipe II a San Hermenegildo", $C D, 77$ (1961), 523-552. El poema latino de Ambrosio de Morales, inserto entre los materiales del tomo de 1587 se titula In diuum Ermenegildum. Regem Martyrem hymnus.

${ }^{12}$ Es de tener aquí en cuenta que no puede darse aún por segura la cronología del poema, variamente fechado por multitud de críticos entre 1551 (Coster) y 1580 (Llobera). El P. Ángel C. Vega lo cree anterior a 1570, pero sin otra base que la afinidad temática de un "grupo clásico-mitológico", si bien "esto no excluye que sufriera retoques hasta en sus últimos años" (Poesías de fray Luis de León, Madrid, 1953, p. 36). Se impone tomar en cuenta la alternativa metodológica de una fecha determinada por la cuestión goticista, tan vivaz en la década de 1580 . Presenció ésta un resurgir general del tema de Rodrigo, iniciado con la publícación de la patrañera, pero convencional, Historia de los reyes godos (1582) del burgalés Julián del Castillo, cuya misma portada pregona "la sucesion dellos hasta el Catholico y potentíssimo don Philippe segundo". La vetusta Crónica sarracina o Crónica del rey don Rodrigo, inédita desde 1549, se reimprime en Alcalá, 1586, y por dos veces (Alcalá y Sevilla) en 1587. Como espero mostrar en otra ocasión, la Profecía del Tajo se relaciona en forma directa con la Sarracina y refleja hasta en su mismo título el ambiente peculiar de la octava década del siglo. $\mathrm{Cu}$ riosamente, el P. Āngel C. Vega admite, incluso, la disparatada posibilidad 
espaciosa y triste España" funde a la de su tiempo con la de Rodrigo, el rey forzador. Y hacia los mismos años de la Verdadera historia debió de escribir el dominico jerezano fray Agustín Salucio (1523-1601) su diatriba contra el mito complementario de los mozárabes ${ }^{13}$, levantado también por Ambrosio de Morales en honor de la pretendida ortodoxia y perseverancia cristiana de éstos ${ }^{14}$.

\section{LA RECTIFICACIÓN ÂRABE}

Sobre todo, el mal ejemplo de Rodrigo y su gente goda queda corregido por el cuadro de la victoriosa conquista del reino por el "virrey" de África Muça el Zanhani y su capitán Tárif Abenzief, "cumplido hidalgo de solar conocido" (I, fol. 17v). Es un proceso metódico, gobernado desde "las Arabias" por el excelso Miramamolín Iacob Almançor. El reino godo va desgranando una a una

de que la Primera Parte de Miguel de Luna (1592) haya podido influir sobre una primera redacción del poema (cuyo autor fallece en 1591). Igual de fantástica resulta su conjetura de que fray Luis de León hubiera conocido la obra de Luna con ocasión de su visita a Granada en 1562 y tal vez tratar y conversar con él" (Poesias, p. 58). No está, por último, tan claro que fray Luis fuese un virulento antisemita (admirador del "sabio moro") y particular enemigo de los moriscos, como ya le levantaron algunos apologistas de la expulsión (Aznar Cardona) y afirman ciertos críticos modernos.

${ }^{13}$ F. LÓPEZ ESTRADA, "Dos tratados de los siglos XVI y XVII sobre los mozárabes", AlAn, 16 (1951), 331-361. El opúsculo de Salucio se titula Del origen de los villanos que llaman christianos viejos. Salucio era netamente favorable a la asimilación pacífica de los moriscos, cuya causa y futuro veía ligados al problema del deshonor colectivo en su Discurso sobre los estatus de limpieza, escrito poco antes de la expulsión: “Quién no ve que siendo perpetua la infamia de los moriscos, si Dios no haze milagros con ellos nunca han de ser cristianos de corazón? Porque si miran a su comodidad temporal, les estuviera mejor que tomaran los moros a España" (A. DOMÍNGUEZ ORTIZ, "Notas para una sociología de los moriscos españoles", Miscelánea de Estudios Árabes y Hebraicos, 11, 1962, p. 53).

${ }^{14}$ Como observa F. López Estrada ("Dos tratados", p. 331) fue Ambrosio de Morales quien puso de actualidad el tema de los mozárabes. Con argumentación de dos filos insistía en la perseverancia de los mozárabes: "A todos estos Christianos sujetos, se les permitió biuir en su ley libremente, y juntarse en sus Iglesias a los oficios diuinos, y a recibir los santos sacramentos, y ser regidos en la fe y religion Christiana por sus obispos, sacerdotes y otros ministros de sus Iglesias" (Corónica general de España, III, fol. 214v). Con argumentos opuestos y de fuerte espíritu polémico, un anónimo defensor de los mozárabes salía al paso de impugnadores como Salucio: "Los moros, con la poca fidelidad que tienen, no guardaron a los mozárabes los capítulos de los conciertos" ("Dos tratados", p. 349). 
sus mejores ciudades (Córdoba, Valencia, Toledo) y sólo Hispala resiste cercada mucho tiempo. El morisco se recrea en narrar las escaramuzas, ardides y heroísmos de estos asedios al estilo "granadino" y abocados a inexorable capitulación, sólo que ahora a favor de los moros. Al tratar de la entrega final de Granada, Luna ensalza sus bellezas, esta vez cobradas en vez de perdidas por su pueblo:

... una cibdad pequeña en alto sitio fabricada, la cual descubria una muy amena y deleytosa vega a la vista, en medio de la qual atrauessaua un muy hermoso rio caudaloso. Los montes de su circuito estauan llenos de arboledas y frescuras, que parecian un parayso en la tierra (I, fol. $28 \mathrm{v}$ ).

Todas estas ciudades firman capitulaciones que son remedo exacto de las otorgadas a los mudéjares de Alfonso VI en adelante. La religión cristiana se beneficia ahora de una regulada libertad de creencia y ello equivale de por sí a un mudo reproche. Otra diferencia fundamental es que dichos pactos se cumplen con escrúpulo por parte de los vencedores y de ello se siguen condiciones de vida estable, en paz y tranquilidad de todos. Naturalmente, se airea aquí la conocida querella morisca contra la abolición del estatuto mudéjar y, en especial, de los capítulos de Santa $\mathrm{Fe}^{15}$, causante del correr de infinita sangre. Mala moral "cristiana" y pésima política, nos está diciendo Miguel de Luna.

Como predomina un clima de temor y los naturales ofrecen escasa resistencia, Tárif manda que no se les hagan "malos trata-

${ }^{15}$ Es la queja recogida de un modo arquetípico por un famoso y arrepentido "colaboracionista" granadino: "Si el rey de la conquista no guarda fidelidad, ¿qué aguardamos de sus sucesores?" (L. P. HARVEY, "Yũse Benegas, un moro noble en Granada bajo los Reyes Católicos", A IAn, 21,1956, p. 302). La violación de pactos revestía especial gravedad para los musulmanes, que veían en esto una obligación de derecho natural, superior a cualquier diversidad religiosa, y una piedra de toque para la superioridad ética y grado de civilización de un grupo humano. La Gran crónica de Alfonso XI, escrita en 1344, presenta la inesperada muerte de los infantes don Pedro y don Enrique en la vega de Granada como acto de justicia divina por haber roto las treguas previa aprobacion del papa; como sabiamente interpreta D. CATALÁN MENÉNDEZ PIDAL, ello es prueba de "Ideales moriscos en una Crónica de 1344", NRFH, 7 (1953), 570-582. Se entiende así la curiosas ponderación de la veracidad en Los dichos o sentencias de los siete sabios de Grecia, un catecismo filosófico-moral de 1543: "Cumple siempre tu palabra/puesto que la des a un moro / que es un precioso tesoro" (Cuatro obras del bachiller Hernán López de Yanguas, Cieza, 1960). Aljofores y literatura aljamiada en general solían apostrofar a España por "quebrantadora de las cosas que juraste" (E. SAAVEDRA Y MORAGAS, "Escritos de los moriscos sometidos al dominio cristiano", Memorias de la Real Academia Española, 6, 1889, p. 159). 
mientos" (I, f. 28v), aunque como en toda guerra no sea posible evitar algunas insolencias aisladas. La reina esposa de Rodrigo (a su vez renegada árabe) es tratada con el mayor respeto, y si está destinada a morir mártir es por un peculiar destino de amor y de política que se verá más adelante. Egilona, hija y no esposa del último godo según Luna, va a casar con Abdalaziz, pero la perspicacia de Godoy Alcántara ${ }^{16}$ señaló en su día que tales libertades y desdoblamientos no son caprichosos, sino forma de sumar un derecho dinástico al campo musulmán. Si existe una legitimidad de sangre, ésta reside según las Partidas en Egilona, y no en don Pelayo, mero consanguíneo del rey don Rodrigo.

Luna no es que pretenda dar a sus árabes de guardarropía un espaldarazo de perfecciones utópicas. Tienen sus defectos y sus virtudes, y como confiesa desde el primer momento sólo desea restituirles y poner en su sitio la "honra natural" que compartieron con sus enemigos cristianos. Se da en el intérprete morisco poco menos que una obsesión por subrayar no la bondad de unos y la maldad de otros, sino la común humanidad de todos, una vez hecho borrón y cuenta nueva de la depravación goda. Tras la batalla decisiva contra Rodrigo, Tárif manda enterrar a todos los muertos, así moros como cristianos, para evitar contagios, dado que sus cadáveres se corrompen por igual. Y en otro terreno más grato se comprueba también que el axioma de que "los yerros por amores eran dignos de perdón"' (II, fol. 88r) es tan aplicable y oportuno entre moros como entre cristianos.

La historia del mundo musulmán inventada por Miguel de Luna abunda en conspiraciones, rebeldías y excesos criminales. La relativa superioridad radica en que entre moros no alcanzan a prosperar, ni quedan impunes las tiranías ni las usurpaciones, como bajo el cetro integralmente corrompido y corruptor de Rodrigo. Cuando el heredero de un rey moro de Valencia llamado (¿cómo no?) Abenbúcar, es "atosigado" pór un pariente usurpador (caso similar al de Rodrigo con Sancho) sus súbditos se alzan contra él "hasta beberle la sangre" (I, fol. 106v). El tiranicidio cumple entre los moros una saludable función y constituye uno de los fondos inquietantes de la "historia" de Luna.

\section{La Asabīya}

Muy en especial, el sabio Abentarique predice con clarividencia el destino a la larga adverso del Islam español, llamado a sucumbir

${ }^{16}$ Historia crítica, p. 98. 
ante los herederos del diminuto y pobre reino de don Pelayo por simple carencia de solidaridad interna: "Y creo para mi que ha de ser causa de la destruyción de todos aquellos Reyes de España, respecto de la grande desconformidad que ay entre ellos" (II, fol. 33v). Por el camino que haya sido, Luna está haciéndose eco de Ibn Khaldun y su crucial observación acerca de la debilidad de la 'asabĩy $a^{17}$ o vínculo tribal que aflige al Islam español y lo aboca a definitiva extinción. "Jamás cupieron dos cabeças en una olla" (I, fol. 77r) responde un avisado califa a la sugerencia de una bipartición del reino. Luna es en esto un nexo importante para la presencia de la misma tesis en Ginés Pérez de Hita, con su maravillosa proyección a través de las Guerras civiles de Granada (1595) que hicieron posible el triunfo de los Reyes Católicos. Presente y funcional en la Primera Parte de Luna (1592), la idea de la discordia civil se desarrolla mucho más en la Segunda (1600) como efecto a su vez palpable del gran logro de Pérez de Hita.

La tendencia irracional del mundo islámico a la "taifa" (término desconocido, pero fundamental como concepto en Luna) es sólo temporalmente contenida por la energía y el prestigio personal de gobernantes. Una contienda dinástica del califato oriental, vagamente similar a la de Omeyas y Abbasíes, determina en España la aparición de los primeros "taifas", escindidos en siete reinos: Córdoba, Granada, Valencia, Murcia, Toledo, Aragón y Baeza. El instinto egoísta y disgregador, sumado al casi único caso de intolerancia religiosa que aquí se registra, malogra en el momento crítico la gran oportunidad histórica del Islam español. Surge ésta cuando una situación de ilegitimidad en el califato oriental permite a Abdaláziz asumir una independencia irreprochable (en cierto paralelo con el caso de Abderrahman I). Unido entonces a Egilona en matrimonio de amor, indiferente a la diversidad religiosa en que ambos perseveran, se halla entonces a punto de originar una dinastía cristiano-musulmana que hubiera reunido todas las legitimidades y privado de razón de ser al forcejeo de los dos pueblos. Pero unos "virreyes" turbulentos y ansiosos de poderío, que acusan a Abdaláziz de querer hacerse cristiano, lo apuñalan un día en su palacio. Egilona, que a la sazón estaba preñada,

${ }^{17} \mathrm{~F}$. GABRIELI, "Il concetto della 'asabiyyah' nel pensiero storico de Ibn Haldun", Atti della Reale Academia delle Science di Torino, 65 (1929-1930), 473-512. I. DE LAS CAGIGAS, Los mudéjares, t. 2, p. 481, nota. A. CHEDDADI, "Le système du pouvoir en Islam d'après Ibn Khaldūm", Anales, 35 (1980), 534-550. Como precisa este último estudio (p. 548), las ideas de Ibn Khaldūn pueden considerarse como una perfecta decantación de la experiencia política magrebí. 
malpare y muere también. Se siguió en todo el mundo musulmán un período de caóticas disensiones, robos y tiranías, "y como los Reinos diuisos y puestos en disconformidad presto son assolados", brindaron a los cristianos la oportunidad de aprovechar tanta "dissensión y guerras ciuiles", porque "hasta allí auían estado adormidos, sin osarse menear a ninguna parte (II, fol. 102v). Corre el año 744 y el rey don Alonso sabe sacar buen partido de las "desconformidades y dissensiones, odios y rencores, assí ocultos como manifiestos" (II, fol. 102r). El bravo general Ugarte tomó a Burgos, tras el sacrificio numantino de todos sus habitantes. Muere el rey cristiano y transcurren dos años esperanzados para los árabes, pues no existía acuerdo acerca de los derechos del heredero don Fruela, por ser éste hijo natural. Pero los sempiternos "alcaides", esta vez cristianos, entendieron bien dónde caían sus verdaderos intereses y terminaron aceptándolo por rey. El nuevo soberano se apoderó en seguida de Setúbal, "en la costa del mar mayor" (II, fol. 105r) y el futuro del Islam no puede hallarse más comprometido a la hora de acabar Abentarique su crónica, allá en la lejana Bucara. Se ha eclipsado por completo, en el curso de muy pocos años, la brillante estrella que lucía para el justo y fuerte Abdaláziz. No hace falta mucha perspicacia para comprender que la muerte de Egilona y el malogro de su hijo era, en realidad, la del ensueño que en vano pretendieron hacer realidad los plomos del Sacromonte.

\section{LA IMPRONTA GUEVARIANA}

El empeño seudohistoriográfico de Miguel de Luna era sumamente ambicioso, pues pretendía ser una crónica general del mundo islámico, que involucraba a España con los sucesos de Arabia, Túnez y Marruecos. El proyecto del morisco era así tan magno como su falta de preparación para acometerlo. Carecía de fuentes sobre el califato Omeya igual que sobre la historia de alAndalus, porque todo aquello era virtualmente desconocido para los españoles de su época ${ }^{18}$ y él mismo era antes que nadauno de

${ }^{18}$ Las dificultades suscitadas al estudio de la lengua arábiga eran en esto un obstáculo insuperable. En 1598 Lupercio Leonardo de Argensola, deseoso de investigar la Edad Media aragonesa, decidió aprender el árabe. Encontró casi imposible hacerse de una cartilla de la lengua y por algún tiempo recibió la enseñanza directa de un tal Urrea, italiano de nacimiento, que había llegado a secretario del sultán turco. Urrea (apellido que adoptó en su bautismo, por cortesía hacia su madrina la condesa de Aranda) fue nombrado catedráti- 
ellos. Le guiaba, sí, una sensibilidad ancestral que, por ejemplo, le movía a diagnosticar con acierto el morbo taifal de los andalusíes, o la perpetua tensión entre Oriente y Occidente en el seno del mundo islámico y que en la época lanzaba al xarife en brazos de una alianza española como contrarresto del poder otomano'. Su modelo "historiográfico" no eran crónicas españolas ni arábigas, ni tampoco la descarada novelización caballeresca de la Crónica sarracina que tenía tan cerca.

La gran pasión de Miguel de Luna y las páginas donde ha ido a la escuela no son otras que fray Antonio de Guevara (1481. 1545), absorbido más a la manera de una droga adictiva que como una verdadera influencia literaria. El morisco había sucumbido, como tantos otros contemporáneos, ante tales modelos de "historia" (y aun de historia "clásica") que se dejaban leer sin sentir, donde el cotilleo se disfrazaba de doctrina moral y el pasado resultaba ser tan gustosamente parecido al presente. Uno y otro encarecen, siempre que pueden, su dependencia de una fuente impecable conforme a lo que, en realidad, era un artificio rutinario de los libros de caballería ${ }^{20}$, o pavonean con idéntico ci-

co de árabe en Alcalá y participó en la clasificación de los manuscritos árabes del Escorial, empresa en la que trabajaba también Alonso del Castillo. Para aquellas fechas Urrea se hallaba desempleado y preparaba una historia de la dominación árabe en España, a base de fuentes orientales, para deshacer los errores de Jerónimo de Blancas y del P. Mariana (O. H. GREEN, Vida y obras de Lupercio Leonardo de Argensola, Philadelphia, 1927, pp. 51-52). Amplios datos sobre los obstáculos prácticos que se oponían a los intentos de iniciación en la lengua son comentados por M. BATAILLON, "L'Arabe à Salamanque au temps de la Renaissance", Hesperis, 21 (1935), 1-17. Sobre el fracaso de los colegios trilingües, J. T. MONROE, Islam and the Arabs in Spanish scholarship (introducción).

${ }^{19}$ D. CABANELAS, "Cartas del sultán de Marruecos Ahmad al-Mansur a Felipe II", AlAn, 23 (1958), 19-47. Gran parte de las negociaciones entre Felipe II y el xarife pasaron por la mano de Alonso del Castillo (D. CABANelAs, El morisco granadino Alonso del Castillo, Cap. 8, "Intérprete de Felipe II"). Para una visión de conjunto sobre la compleja diplomacia norteafricana en esta época. J. Olliver Asín, Vida de don Felipe de África, principe de Fez y de Marruecos, Madrid-Granada, 1955.

${ }^{20}$ Lista cronológica en L. MORALES OLIVER, La novela morisca de tema granadino, Madrid, 1972, p. 146. La raigambre de Cide Hamete en este tradicional artificio y la cercanía de Tárif Abentarique al personaje cervantino fue observada por Godoy Alcántara (Historia crítica, p. 10). Por otra parte, la falsificación basada en una supuesta fuente árabe se remonta hasta el siglo XIII con la Estoria del Cid, que un monje de Cardeña hizo pasar como traducción de un libro de Abenalfarax (Ibn al-Faraŷ), el alguacil histórico del Cid en Valencia (D. CATALÁN, "Poesía y novela en la historiografía castellana de los siglos XIII y XIV", Mélanges Rita Lejeune, Gembloux, 1969, t. 1, pp. 430-431). 
nismo la vida de estudio y muchos años de ímproba labor que hay detrás de sus respectivas "traducciones". Luna saquea a Guevara en lo grande como en lo pequeño, reelaborando, por ejemplo, la historia de Andrónico y el león de Epistolas familiares ${ }^{21}$,resumida como aventura de Abdaláziz con un oso. Para mayor coincidencia, el libro de Luna lleva en su centro un "Marco Aurelio", sólo que disfrazado esta vez de moro y no de romano. Es la vida ejemplar del Miramamolín Iacob Almançor, escrita originalmente por el alcaide Alí Abençufián en el más arduo compromiso, "para lo qual hurté a mis grandes ocupaciones algunos ratos de noche, cercenando el sueño, en el qual auía de descansar este miserable y cansado cuerpo" (II, fol. 3v). Todo para mostrar, en riguroso paralelo con el Relox de príncipes, "las condiciones que deue tener y guardar el buen Rey para ser amado y querido de los suyos, y temido de sus enemigos" (II, fol. 2v).

Deslumbrado por el "alto estilo" guevariano, Luna se esfuerza por exprimir de su pedestre cálamo algún que otro ejemplo de inconfundible similiter cadens: “... y pareciéndole al Abdaláziz que la empresa era dificultosa, y la vitoria muy dudosa..." (II, fol. 55v). La Verdadera historia se basa además en la fórmula guevariana de concentrar la esencia narrativa en supuestos discursos, leyes y epístolas de los protagonistas del drama histórico. Tuvo en esto cierto éxito, pues la carta de Florinda para contarle al padre su desgracia "por semejas" y que a Menéndez Pelayo pareció "poco limpia", se vólvió casi obligada en toda otra versión posterior de la leyenda de Rodrigo's2.

Esta elección del modelo guevariano resulta fundamental para entender a Miguel de Luna, pues muestra que en realidad no deseaba ser tomado a la letra ni pergeñar una falsificación técnicamente en regla. Si no era lo bastante artista para asimilar sino lo más superficial de Guevara, comprendía con lucidez las perspectivas abiertas por aquella seudohistoria y seminovela-ensayo guevariana $a^{25}$. Le ofrecía ésta un vehículo de probada eficacia para

${ }^{21}$ Epístolas familiares, ed. J. M. de Cossío, Madrid, 1950, t. 1, 28, pp.170 ss.

${ }_{22}$ Menéndez Pelayo señala el germen de la famosa carta en el mismo Rasis, a quien calca en esto Pedro de Corral. Tras Luna se ensayaron en el mismo ejercicio epistolar Saavedra Fajardo y José Cadalso (Orígenes de la novela, t. 2 pp. 96 y 105). Menéndez Pidal pone en la lista a fray Bernardo de Britto y a Lope de Vega (Floresta, t. 2, pp. 57 y 64).

${ }^{23}$ F. MÁRQUEZ VillanUeVA, "Fray Antonio de Guevara o la ascética novelada", Espiritualidad y literatura en el siglo XVI, Madrid, 1968. "Fray Antonio de Guevara y la invención de Cide Hamete", Fuentes literarias cervantinas, Madrid, 1973. 
acercarse a una gran masa de lectores, a un público semiculto ante el cual exponer un alegato imposible de airear por otro medio, y ello era cuanto Luna podía desear. No es culpa suya (como tampoco lo fue de Guevara) que en el posterior desastre de la historiografía española creyesen en su Abulcácim muchos que no debieran.

\section{HISPANIZACIÓN}

Guevara contamina también a Luna la vergonzante hispanización antiarqueológica de una visión a sabiendas seudohistórica. Instituciones, artes y oficios, el mundo de las cosas y no se digan los modos de enjuiciar y sentir, permanecen en ambos casos hondamente hispanos y contemporáneos. A Luna no le importa, por ejemplo, presentar a los califas de Arabia reuniendo Cortes en las mismas circunstancias que lo habrían hecho Carlos V o Felipe II (servicios extraordinarios, jura de herederos, etc.). Igual que en el modelo de Guevara, la historia que pretendía contar no era sino una pura actualidad, un presente y no un pasado. La diferencia es que lo que en el obispo había de lúdico se tornaba para el morisco en angustiosa urgencia de influir sobre la amenazadora actualidad que tenía a su alrededor. Porque dicha fórmula de hispanización anacrónica servía idealmente a su tesis negadora de un abismo insalvable para moros y cristianos de buena voluntad.

El lector de Luna se pasea de este modo por una historia "arábiga" que le resulta un déjà vu familiar. Tárif, por ejemplo, quema las naves como medio de esforzar a los suyos, exactamente igual que Hernán Cortés en Veracruz. Este mismo capitán muere años después a consecuencia de una batalla acarreada en un conflicto dinástico, "herido en un braço de una pequeña herida, de la qual no auía hecho caudal, con el camino se le espasmó el braço de cuya causa murió dentro de pocos días" (I, fol. 62v); todo lo cual no es sino repetir (o anticipar, según se mire) la muerte del infante don Enrique de Aragón tras la primera batalla de Olmedo (1445), que de tal modo impresionó a la imaginación popular. No es menos notable que entre los hijos del Miramamolín Iacob Almançor surgiera también una contienda fratricida calcada sobre la de los Trastámara. El heredero legítimo Abilgualit, destronado por su hermano Abrahem el Amçari, ha de refugiarse en Túnez y el usurpador, naturalmente, se vio obligado a hacer "muy señaladas mercedes a todos aquellos Alcaydes y cortesanos sus criados" ( $I$, fol. $58 \mathrm{v}$ ). Pero el violento Abrahem, que personal- 
mente solía degollar a sus enemigos en el campo de batalla, murió a su vez combatiendo contra su hermano. Luna hace aquí varias trampas con la historia: como el principio de legitimidad no ha de ser lesionado, tendrá que ganar al final el rey "don Pedro". Pero no un "Cruel" que llamara al tiranicidio, pues dicho sangriento papel se le endosa precisamente al vencido "Trastámára". Se afea también, de paso, el proceder de Enrique II, pues Abilgualit sólo tenía intención de tomar preso a su hermano, al que amaba tan de veras que mandó guardar por él luto y hacerle solemnes exequias. El morisco tacha de indigno todo el desenlace de Montiel y recuerda su pecado de origen a la dinastía reinante. Su historia arábiga se muestra como un correctivo de la España cristiana y no tolera cierta clase de excesos. No es cosa de que en ella triunfen tan claramente los "malos".

Otras veces hay un maligno placer en saldar por simple inversión las viejas cuentas sentimentales. Ya se ha visto cómo son ahora los cristianos quienes han de sufrir la amargura de verse poco a poco desposeídos. Suena para Granada y Sevilla, ciudades incomparables, la hora de caer en manos musulmanas. Esta última resistió el asedio por muchos años (hasta el 730), pues le entraban por su puerto fluvial bastimentos enviados "de una tierra fragosa, que llaman los Christianos por nombre Vizcaya" (I, fol. 53v). El rey de Córdoba Abulcácem Habdilbar, con alguna ayuda del de Baeza, consiguió bloquear el río con dieciocho fustas. Su defensor, el heroico alcaide Sarmató, murió abrumado de heridas y de trabajos. Los cercados hispalenses pidieron ayuda a don Pelayo para que los socorriera "por la vía de Vizcaya" (I, fol. 103r), pero el cristiano carecia de posibilidades para tal empresa, harto ocupado en defender su pobre reino, y sólo pudo ofrecerles una triste simpatía. Fue preciso resignarse a pactar una capitulación en la que, al menos, el cordobés se comprometía a "que no haría fuerça él ni otro por él a los Christianos de hazerles dexar su ley (I, fol. 103v).

El juego tiene poco de inocente, pues nunca deja de encubrir alguna clase de arremetida contra la España cristiano-vieja y sus mitos. La historia más reciente tampoco escapa incólume. El rey Abencirix de las Arabias juntó un formidable ejército expedicionario para someter a un alcaide rebelde en el reino de Túnez. Dio su mando a otro alcaide "de quien hazía mucha confiança", pero "con los malos temporales que passó en aquella nauegación, tuuo entendido por muy cierto que auía de perecer él y todos los suyos" (I, fol. 78r). Aunque logran desembarcar, fueron completamente derrotados. Nituralmente, estamos ante un híbrido del fracaso de Carlos V ante Argel en 1541 y de la aciaga 
jornada de Inglaterra en 1588. Abencirix apuró entonces el mismo cáliz de un Felipe II:

Llegada la nueua de la pérdida de esta armada al Rey Abencirix, recibio mucho pesar y tristeza, y creciole mucho mas en ver que no tenía possibilidad qual conuenia para poder armar de nuevo, y vengar su injuria, y assi determino por entonces de dexar aquella guerra, hasta que huuiesse mejor ocasion para conseguir su designio (I, fol. 78v).

Pero Abencirix pudo rehacerse con gran sacrificio de sus reinos y envio contra Túnez otra armada aún más poderosa. La contraria era mandada por un hijo del rebelde, llamado Abrahem Hacem, "el qual aunque no tenía mucha edad, tenía grande esfuerço y valor, y era muy belicoso y buen marinero y sabía muy bien ardides de guerra" ( $I$, fol. 81r). Los rebeldes fueron esta vez derrotados en el mar, si bien el joven trasunto de don Juan de Austria pudo escapar en una fusta rápida. El híbrido histórico se complica asî con otra evocación de Lepanto, convirtiéndose en cifra de la historia naval española de aquel siglo. Aparte de otras implicaciones, hay una moraleja bien clara: aquellos reyes de Arabia sabían salirse con la suya y eran más poderosos que Felipe II.

\section{IACOB ALMANÇOR}

Nada, por este camino, de mayor interés que la vida ejemplar del rey Abilgualit Miramamolín Almançor, bajo el cual se realizó la conquista de España. Semejante espejo de perfección para "todos" los príncipes del mundo, reverso del godo Rodrigo, es el personaje central del libro de Luna. El cariño puesto en el cuento de sus virtudes confiere, por primera y única vez, cierta belleza elemental a esta sección de la obra. Es un gobernante justiciero, sabio y piadoso. Ante todo, es un epítome de la ciencia oriental, pues antes de los veinte años escribió ya libros de matemáticas, álgebra, arte militar, un Espejo de príncipes, comentos de Aristóteles, y para los veinticinco hablaba once lenguas. Más allá de todo convencionalismo, Luna hace de él una figura polémica, otorgăndole virtudes muy a contrapelo de las practicadas por la España oficial de su tiempo:

No tenia atencion a sangre, ni menos a altos linages, porque si era hombre particular de mediana condicion, y tenia valor para regir y gouernar le daua el mejor lugar y cargo de sus consejos. Y si era hombre de gran linage, y no tenia valor, no hazia caudal para seuirse del en cosa alguna (II, fol. 1lr). 
Fue cosa digna de notar que jamás se aueriguo que nadie le pidiese limosna y socorro, otra fuesse Moro, Christiano, o Iudio, o de otra qualquiera nacion que boluiesse desconsolado (II, fol. 14r).

Enemigo mortal de la ociosidad, dedicaba los miércoles a descansar con humildes tareas manuales, nada alejadas por cierto de las más propias de los moriscos españoles:

Y alli a sus solas labraua de manos astrolabios de Astrología, y otros instrumentos de gran primor, los quales eran muy estimados entre los hombres sabios de su tiempo. Otras veces labraua de taracea $\tan$ delicadas cosas y de tanta estimacion, que maestros muy peritos en aquel arte tomauan dechado y licion de las pieças que acabaua de su mano, porque para todas estas cosas tenia singular ingenio y grande primor y sutileza. También labraua ballestas y otros generos de armas, mayormente cotas de malla, que yo soy testigo que vi vender una (que el auia dado a un $\mathrm{Al}$ caide priuado suyo) a peso de plata (II, fol. 15r).

El buen soberano fomenta así una tabla de valores de signo calvinista o burgués absolutamente opuestos a la jerarquía e idea de la honra en la sociedad cristiano-vieja de la época. Iacob Almançor puso también ley de que

... qualquier persona de qualquier estado y condicion que fuese, que no tuviesse oficio en que ocuparse, fuesse auido por infame, y hombre sin honra: lo qual fue causa que a su imitacion todos sus subditos huyan de la ociosidad, y se ocupauan en oficios virtuosos: con lo qual se escusauan muchos vicios y maldades y viuian sin tener necessidad (II, fol. 19r).

Incluso un "taifa" granadino, llamado Betiz el Zunici, respondió a la presión militar de Abdaláziz con hacer hijosdalgo a todos sus súbditos, mejoras de la agricultura, laboreo de nuevas minas y fundación de colegios para mayor prosperidad de las Letras.

No hay en todo esto ningún misterio. Tales ideas de documentan en la Segunda Parte, publicada en 1600. Quiere decir que aquellos textos de Luna acusan una inmediata reacción a las ideas expuestas por los Discursos del amparo de los pobres publicados en 1598 por el doctor Cristóbal Pérez de Herrera ${ }^{24}$, representante máximo del arbitrismo reformista. Se prolonga la coincidencia con el mismo en la preocupación del Miramamolín por el fomento de las ciencias físico-matemáticas y de hospitales para los verdaderos pobres: "Del modo y manera con que auía man-

${ }^{24}$ Ed. M. Cavillac, Madrid, 1975. Las ideas de Pérez de Herrera ejercieron una decisiva influencia sobre Mateo Alemán, expresamente reconoci. da por éste en documento publicado por E. Cros, Protée et le gueux, París, 1967, p. 433. 
dado leer las ciencias en sus Reynos, y de las Academias y Hospitales que mandó fabricar, y dotar para ellas, y para los enfermos pobres" (II, fol. 16r). Iacob Almançor dedicaba un día entero de la semana a reunirse con los sabios en su espléndida biblioteca privada. Construyó, además, junto a su palacio, un hospital en el que maestros a sueldo enseñaban las ciencias y se proveía de libros, vestido y alimento a estudiantes pobres, que recibían después sus grados sin pago de ninguna clase de derechos. El soberano visitaba personalmente este hospital-academia para atender a las necesidades de enfermos y estudiantes. Entre estos últimos escogía los alfaquíes para las mezquitas y los cadís para su justicia (léase alto clero y hombres de garnacha, asî como una crítica del favoritismo legalizado de los colegios mayores). Soldados viejos o enfermos y pobres vergonzantes le merecían, para colmo, la misma solicitud que para los mismos deseaba el susodicho reformista, un converso favorable en aquella sazón a los moriscos ${ }^{25}$.

Las anacrónicas y buscadas ambigüedades continúan también, multiplicándose, pues Iacob Almançor gobernaba a través de Consejos no menos burocratizados que los de la monarquía española. Hasta respondía cuanto "se decretaua a las espaldas de las cartas" (II, fol. 10r), con lo cual podía presumir de roi paperassier igual que Felipe II. Más curioso aún es que, sintiéndose viejo y cansado, renunciara en su hijo para "recogerse a una sierra donde tenía una casa de plazer, con muchos jardines y frescura" (I, fol. 55r), con una mezquita al lado, habitada por un morabito y cuarenta discípulos o monjes. Para acompañarle "escogió algunos fieles y leales criados suyos, quales le parecio que conuenían para que le siruiessen en aquel recogimiento que hazía" (I, fol. 56v) y del que Dios no permitió que gozara mucho tiempo. Tan obvio plagio de la abdicación y retiro de Carlos $\mathrm{V}$ viene a confirmar, de nuevo, que moros y cristianos son parecidísimos en la virtud, orientalizando retrospectivamente al Emperador y haciendo de Miramamolín un doble suyo.

Tras esta permistión de ambos personajes, importa mucho notar que Iacob Almançor supo en su "Yuste" oriental, por medio de viejos alcaides, del gobierno poco brillante de su hijo, al que dirigió una carta de amargas reflexiones político-morales: "Y también deueys considerar que vuestro gobierno es desorden, vuestra justicia es injusticia, vuestra misericordia es inclemencia, vuestra caridad auaricia, vuestra largueza y diligencia accidia"

${ }^{25} \mathrm{M}$. Cavillac, "Noblesse et ambiguités au temps de Cervantes: le cas du docteur Cristóbal Pérez de Herrera", MCV, 11 (1975), 177-212. 
(II, f. 21r). Tales admoniciones, teste Tárif y el alcaide Abençufián, fueron eficaces para enderezar los pasos del claudicante sucesor.

La vida ejemplar de Iacob Almançor ilustra la espontánea y necesaria fundación del poder $(m u l k)$ en el prestigio moral de la persona constituida en autoridad, conforme a otro de los principios cardinales de la teoría política islámico-magreb $\mathbf{1}^{26}$. Delimita, además, una clara intención de Luna, perfectamente captada en su día por Godoy Alcántara: "El autor echaba a volar este retrato de soberano perfecto: ¿quién sabe si llegando a penetrar hasta la corte del Escorial contribuiría a que modificara sus disposiciones para con la gente de su raza?" 27 . Lo que menos importaba a Luna era, pues, escribir la historia de ningún califa o miramamolín. El único Señor de los Creyentes que' tenía en su mente era el que reinaba sobre los católicos españoles e iba a decidir muy pronto la suerte del pueblo morisco.

Fórmulas Del COLORIDO ORIENTAL

Luna sorprende por el grado de su ignorancia acerca de la historia de al-Andalus, que para él cuenta sólo como la tristeza de una oportunidad frustrada. El paso de ocho siglos se encapsula a paso de caballo en el supuesto transcurso de unos cincuenta años. En ellos se suceden la conquista inicial, rebelión de unos "taifas", restauración del poder legítimo, independencia hispanomusulmana y caída posterior en la decadencia irreparable de una segunda etapa de "taifas". Sus fuentes directas y efectivas son Ambrosio de Morales y la Crónica del rey don Rodrigo o Crónica sarracina de Pedro de Corral, a la que claramente intentaba desbancar en el favor del público ${ }^{28}$. Tanto Corral como después Morales usaron con independencia la Crónica del moro Rasis, centón nada escrupuloso de un autor del siglo X (Ahmad al Rãzī) accesible en traducción castellana al menos desde la primera mitad del siglo $\mathrm{XIV}^{29}$. Por ser casi el único ejemplo de historiografía hispanoárabe 540.

${ }^{26} \mathrm{~A}$. CHEDDADI, "Le système du pouvoir en Islam d'après Ibn-Khaldūn", p.

${ }^{27}$ Historia crítica, p. 100.

${ }^{28}$ Lo observó con su habitual sagacidad Godoy Alcántara (Historia crítica, p. 8), aunque reduciendo de modo algo simplista el alcance de los propósitos de Luna.

${ }^{29} \mathrm{C}$. MICHAËLIS DE VASCONCELOS, André de Resende e a crónica do Mouro Rasis, Lisboa, 1922. Con anteriodidad, la Crónica de Rasis había 
que tenían a mano, la Crónica vino a ser de dominio público para los autores de esta época. Luna, curiosamente, no da indicios de haberla conocido en cuanto tal hasta su Segunda Parte de 1600. Inserta en ella una descripción de España inspirada por el compendio similar con que se inicia la obra de Rasis ${ }^{30}$. Tan es así que Luna se excusa en aquel punto por no haber seguido este mismo plan, llevado de la necesidad de echar por delante "la causa prin-

introducido en la España cristiana importantes elementos de la leyenda de Rodrigo, que Menéndez Pidal identifica ya en la historia del toledano Ximénez de Rada, de enorme influencia posterior (Floresta, t. 1, pp. 78 ss.). Rasis sirvio de base a un proceso de novelización posterior, culminado en la Sarraci$n a$ como estudió Menéndez Pelayo (Orígenes de la novela, t. 2, pp. 93 ss.), pero visible ya en la misma Crónica de 1344 (Floresta, 1, pp. 83 ss). La traducción portuguesa de ésta produjo la curiosidad de una discutida retroversion al texto lusitano, según L. F. LiNDLEY CinTRA, Crónica geral de Espanha de 1344, Lisboa, 1951, I, Pp. LI-LXIV. En el siglo XVI circularon bastante los manuscritos de la versión castellana del siglo XVI, muy manejados por los autores interesados en antiguallas godas o hispanomusulmanas, como Ambrosio de Morales, Argote de Molina y Luis del Mármol Carvajal. Morales se refiere a ella en su Coronica general de España (1586): "Fue Rasis coronista de Miramamolín de Marruecos y rey de Córdoba Dalharab. Y el original yo tengo de su historia en Castellano, ha más de dozientos y cinquenta años que se escriui6" (fol. 102v). José Antonio Conde juzg6 en los más duros términos esta version romance del Moro: "La historia que se dice del Moro Rasis... es una mezquina compilación de los bárbaros cronicones antiguos, con algunas noticias tomadas de malos libros arábigos: toda llena de errores, y fábulas absurdas. Únicamente merece alguna consideración en la parte geográfica, que aunque muy depravada sirve en este punto para el conocimiento de aquel medio tiempo. Es asimismo tan escasa, como bárbara y ruda; y no contiene más que los nombres de algunos Reyes de Cordoba ... con la autoridad y nombre de este historiador arábigo Iza ben Ahmed Razis, que ciertamente escribió historia de España, que citan muchos escritores árabes, se han esparcido no pocas fábulas en las crónicas castellanas" (Historia de la dominación de los árabes, t. 1, pp. IX.X). Modernamente sólo se han publicado algunos fragmentos de la versión castellana por PASCUAL DE GAYANGOS, "Memoria sobre la autenticidad de la cronica denominada del moro Rasis", Memorias de la Real Academia de la Historia, Madrid, 1852, t. 8.

${ }^{30}$ Dicha descripción sirvió de base esquemática a casi todos los gé́grafos árabes, a pesar del carácter sumario caprichoso que señala R. LÉVI-PROVEN. ÇAL, "La Descripción de l'Espagne d'Ahmad al Razi", AlAn, 18 (1953), 51108. Como ha señalado J. T. Monroe, todavía le prestaba crédito LUIS DEL Mármol CARVAJAL en su Historia del rebelión de los moriscos de Granada, publicada también en 1600 (Islam and Arabs in Spanish scholarship, pp. 1718). Es muy probable que esta obra de Mármol, de conocimiento obligado para Luna y que muy bien pudo conocer manuscrita, atrajera el interés de éste hacia el moro geógrafo y su legendaria crónica, cuya sustancia se le había comunicado hasta entonces a través de Pedro de Corral y de Ambrosio de Morales. 
cipal de la pérdida de España, los enredos, traiciones y marañas" (II, fol. 30:) que el rey don Rodrigo usó contra la familia real lo mismo que contra el último de sus vasallos. Apenas hay episodio semihistórico que no se justifique por alguna de estas fuentes, sin que ni siquiera se echen de ver muchas sombras de las consejas que acerca de Rodrigo circularon hasta el final en la España musulmana $^{31}$

El único problema de Luna se reducía a dar algún sabor exótico a su pastel hispanoarábigo. Y para esto sí que venía en su ayuda una fantasía de cuento oriental ${ }^{32}$ que sin duda latía vigorosamente en sus adentros. Uno de los mejores ejemplos es la misma carta "por semejas" de la Cava, cuyo texto glosa el simbolismo de ir acompañada por el envío de una gema partida:

$Y$ es que teniendo yo esta sortija que va dentro desta carta con esta engastada esmeralda, sobre una mesa suelta y descuidada (joya de mi y de los míos tan estimado ${ }^{38}$ como es razon) cayo sobre ella el estoque real y desgraciadamente la hizo dos pedaços, partiendo por medio la verde piedra, sin ser yo parte de remedialla (I, fol. 12r).

Una sensibilidad despierta y el arca de una memoria bien provista le proporcionan cuantos fondos y retazos fantásticos

${ }^{31}$ La leyenda misma de Rodrigo se considera de remoto y último origen gótico, si bien sus ecos y variantes arábigas llegan a documentarse hasta en Persia por H. KRAPPE, "Une version orientale de la légende de Rodrigo, dernier roi visigoth", $B H i, 18$ (1926), 176-179. Los temas legendarios de Rodrigo ciertamente circularon en la Granada nazarí hasta el mismo siglo XV, como comprueba F. DE LA GRANJA, "La «Maqama de la peste» del alfaquí ' Umar de Málaga”, AlAn, 23 (1958), p. 111. Aunque es fácil conceder a priori la presencia de elementos legendarios directamente acogidos por Luna, Menéndez Pidal sólo puede señalar la consideración negativa de la Cava como "mala mujer", opuesta a la simpatía que hacia ella muestra el Romancero y fundada en posibles tradiciones locales granadinas (Floresta, t. 2, pp. 53 y 55). Conviene reccrdar a esto que la Sarracina no era tampoco nada benévola con la hija de don Juliân, a la que incluso llama "fija de Satanás". En realidad, Luna no parece haber hecho ningún esfuerzo especial por rebuscar este tipo de materiales populares sobre Rodrigo, acerca del cual repite o fantasea a tenor de finalidades para las que aquél es sólo un pretexto. Sus alardes arqueológicos se aprecian en la diplomática de supuestos documentos califales y en sus traducciones de epitafios, es decir, en aspectos muy relacionados con su profesión de intérprete oficial.

${ }^{32}$ La España medieval debió de conocer alguna recensión hoy perdida de Las mil y una noche. Los moriscos, por su parte, conservaban algunos de sus cuentos en versiones aljamiadas según datos de A. GONZÁLEZ PALENCIA, "El Islam y Occidente", Moros y cristianos en la España medieval, Madrid, 1945, p. 40.

${ }^{33} \mathrm{Sic}$ en la presente edición. Estimada en las posteriores. 
puedan hacerle falta. Así la conseja del caballo de metal con que protegía a Granada su rey Bétiz Abenhabuz (reelaborada por Washington Irving $)^{34}$, o el caso de los facinerosos a salvo en una ciudad inexpugnable por disponer intramuros de multitud de colmenas, y para cuya rendición fue preciso atrapar primero a las abejas con sábanas enmeladas. Un maquiavélico alcaide aniquila de un golpe al rey y a todos los suyos, invitándolos a un sarao preparado ad hoc en el pabellón de un espléndido jardín; dicho edificio se sostenía sobre columnas de sal, con un dispositivo hidráulico que permitía inundar a voluntad los cimientos; en el instante oportuno el conspirador abre los caños y la techumbre se desploma poco después sobre los festejantes.

Igual que en Pérez de Hita, si bien en forma elemental, Luna se sirve también del romancero fronterizo como contexto de ficción por sí mismo evocador de la buscada nota oriental. Un mensajero de Tárif a los valencianos cercados es muerto de un alevoso saetazo por un guarda de la muralla, en inversión de la suerte del adelantado don Diego de Ribera en el romance de $A$ lora, la bien cercadd ${ }^{35}$. Y el rey Iacob Almançor, también por excelencia "moro de la morería", qué duda cabe que no había de decir mentira en toda su vida, como tanto gusta de encarecer su biógrafo. El romance de Abenámar (con su homenaje a la veracidad que enaltece a los moros sobre los cristianos) le cargaba, además, de razón para adoctrinar a su hijo: "No digáis mentira, porque no ay cosa más vil en el mundo, y el mentiroso es discípulo del demonio, y hombre sin virtud, traydor a la verdad, y enemigo della" (II, fol. 22r).

Alicortado para crear, obraba en Luna una tendencia al aprovechamiento mecánico de formas literarias. Cedió, incluso, a la tentación de poner la mano sobre la historia de El Abencerraje y la hermosa Jarifa, reina y manantial de la novela morisca. La utilizaba al contar la suerte de Egilona, salvada muy niña de la catástrofe goda por un buen servidor y criada entre los hijos de éste en la ciudad de Iliturgi, con todas las complicaciones esperables al llegar la doncella a edad núbil. Sólo que Luna no deja que la poesía se le suba a la cabeza y descarrila el relato para mostrar con él la virtud de Abdaláziz, respetuoso de la castidad de la niña. Y todo queda así en un toque final al sostenido contraste de sus árabes con los procederes brutales y afrentosos del rey don Rodrigo.

${ }^{34}$ Tales of the Alhambra, "Legend of the astrologuer".

${ }^{35}$ R. MENENDEZ PIDAL, Flor nueva de romances viejos, Buenos Aires, 1962, p. 205. 
Nada distrae a Miguel de Luna de su propósito de contrariar los prejuicios de la España oficial, suscitándoles las peores dificultades de orden "histórico". No se abstuvo tampoco de pintar como querer en el tema de los primeros pobladores de España. Contra la tradición isidoriana, favorable a Túbal, quien tras el diluvio vino a habitar en ella fue Sem, hijo de Noé ${ }^{36}$. Pero un Sem apellidado Tofáil y, por lo tanto, árabe de pura cepa. Este Sem Tofáil, padre de una España claro está que "semítica", fue astrólogo, matemático y filósofo natural, es decir, lo más "laico" que cabe pedir. Abentarique encontró en Mérida, ciudad fundada no por los romanos, sino por este venerable patriarca, una lápida arábiga en que constaban estos datos y que los expertos descifraron con dificultad (igual que los plomos granadinos). Después, la Península estuvo abierta a la invasión de todo el que quiso: griegos, armenios, cartagineses, vándalos, suevos, romanos, godos, hebreos y finalmente los árabes, en proceso que "sería nunca acabar" (II, fol. $33 v$ ) y por el que escasa culpa puede caber a éstos.

En una época en que las principales iglesias españolas se tiran a matar por el girón de púrpura de la primacía, y cuando Toledo y Burgos inician toda sesión de Cortes con una disputa ritualizada sobre precedencia, Luna decide hacerse campeón de Córdoba en cuanto cifra de un pasado glorioso. Los cordobeses rebeldes se someten a Abdaláziz bajo condición de "que el assiento y cabeça del Reino de España no lo mudaría el rey Abencirix, ni él en su nombre en ningún tiempo a otra parte fuera de aquella ciudad, sino que siempre fuesse corte, y cabeça del Reino de España, como hasta allí lo hauía sido, assí en tiempo de Moros, como de Christianos" (II, fol. 76r). Es un golpe antiburgalés ${ }^{37}$, antitoleda-

${ }^{36}$ En Génesis 10, 21 Sem es antecesor de caldeos y pobladores de Arabia. Sobre el mito de Túbal, véase M. R. LIDA DE MALKIEL, "Túbal, primer poblador de España,', Ábaco, 1970, t. 3, pp. 9-47.

${ }^{37}$ Las ciudades castellanas recibieron con hostilidad casi general a los moriscos expulsados tras la guerra de Granada (A. DOMíNGUEz ORTIZ, "Los moriscos granadinos antes de su definitiva expulsión", Miscelánea de Estudios Árabes y Hebraicos, 12/13, 1963-1964, 113-128). Es de recordar, en particular, una especial enemiga de Burgos hacia los moriscos, que se mostraba reacia a aceptar en 1570 ( $T$. LÓPEZ MATA, "Burgos en la sublevación de los moriscos de Granada", Boletín de la Real Academia de la Historia, 141, 1957, p. 370). Toledo, por otra parte, significaba en la época una continuidad visible del mito neogótico. Los toledanos se dedicaron durante el siglo XVII a desvirtuar por todos los medios el carácter mudéjar de sus monumentos (L. TORRES BALBÂS, "Por el Toledo mudéjar: el Toledo aparente y el oculto", AlAn, 23, 1958, p. 426). 
no y antimadrileño. Luna no oculta la antipatía que le infunden Castilla y las gentes del Norte de España. El reino de don Pelayo se describe como frío, estéril y de mal temperamento. En España se hablan las lenguas árabe, griega, hebrea, gótica y romana, "demás de muchas otras gerigonças, de que no se deue hacer cáudal" (II, fol. 33v) y hay que perdonarle la forma de señalar a la lengua vasca. Los habitantes del Mediodía son "discretos", pero los septentrionales "son toscos, villanos y grosseros, y muy diferentes en todas sus costumbres, trages, ánimo y valor de personas, que no parecen a los Meridionales casi en cosa alguna, y también el lenguaje es más bárbaro" (II, fol. 35r). Luna es andaluz cerrado y militante, que reprocha el abandono centralista y pro-castellano de su tierra natal. Ama con pasión sus ciudades incomparables y, frente al dogma de "que se non podía llamar rey de España quien a Toledo non touiesse" "38, dice de $H$ ispala que "el rey Almançor no se podía llamar con justo título señor de España, hasta ganar aquella ciudad" (I, fol. 51r). Cuando razones geopolíticas forzaron a Abdaláziz a trasladar su corte a Sevilla para estar más al tanto de los asuntos de África, dejó la Audiencia Real en Córdoba para no violar la palabra empeñada. Había fundado allí anteriormente una gran universidad. Lope de Vega, situado al otro extremo ideológico, gritaba desde las tablas:

\section{¡Mueran los moros traidores! ¡Viva Castilla la Vieja! ${ }^{39}$}

Luna aborrece también a los villanos, que en aquellos mismos años van a pasar de imágenes teatrales de la rudeza a cifras de la más alta dignidad humana ${ }^{40}$. Los árabes encontraron defendidas

${ }^{38}$ Así en la Refundición de la Crónica de 1344, realizada hacia 1440 por un judeoconverso toledano (R. MENÉNDEZ PIDAL, Floresta, t. 1, p. 91).

${ }_{39}$ Ya anda la de Mazagatos, en Obras dramáticas de Lope de Vega, Madrid, 1930, t. 10, p. 529 (existen dudas acerca de la transmisión textual de esta comedia). La controversia acerca de los moriscos no registra ideas más peregrinas que las expuestas en 1584 a Felipe II por el licenciado Antonio de Córdoba, partidario de trasladar a Sayago los moriscos granadinos asentados en Toledo. En aquella "tierra flaca y lexos de la mar" no podrían menos de perder su fiereza y espíritu rebelde. A su vez, los buenos sayagueses serían llevados a Toledo "para que sirvieran de soldados mosqueteros y guardasen la ciudad y se ejercitaran las fiestas en cosas de guerra y los días de trabajo labrasen las heredades" (P. BORONAT y BARRACHINA, Los moriscos españoles y su expulsión, Valencia, 1901, p. 316).

${ }^{40}$ Proceso estudiado por N. SALOMON, Recherches sur le thème paysan dans la 'comedia' au temps de Lope de Vega, Bordeaux, 1965. 
las Alpujarras por grandes partidas de villanos, invencibles hasta que uno de éstos, llamado Fandino, los vendió en el barranco de Tocos, "usando de trayción contra su propia sangre y patria, como maluado" (I, fol. 29v). Y fue difícil de averiguar el final de don Rodrigo, pues el pastor con quien trocó sus vestes reales, "como buen rústico que era de pocas palabras y menos razones" (I, fol. 25r), apenas sabía expresarse. Es la clase de enemiga captada por uno de los episodios finales de la novela de Ozmín y Daraja en el Guzmán de Alfarache (1599).

No hay por lo demás nada de especialmente recóndito en esta historia imaginada por Luna y en la que los musulmanes trazan el programa político-social y religioso que debería seguir y no sigue la España de su tiempo. Son, sobre todo, lecciones oportunamente predicadas en torno a aspectos candentes del problema morisco. Cuando Abdaláziz desembarca en Algeciras para someter a la coalición de "taifas" rebeldes, promete la nobleza a cuantos vengan a sumársele. Todos los que estuvieron a su lado en el momento decisivo recibieron el privilegio de "que fuessenauidos y tenidos de allí adelante por hombres hijos dalgos, y que gozassen de las preheminencias, franquezas y libertades que los tales gozauan" (II, fol. 72v). Para mayor firmeza se inserta alli el texto completo del documento que los declaraba "para siempre jamás... auidos y tenidos por hombres nobles hijos dalgo de buena generación", habilitados, con su descendencia, para el desempeño de honores y cargos según lo que "el fuero de la Arabia ordena y manda" (II, fol. 74r). Las alusiones no podían pasar desapercibidas cuando un sector de opinión moderada ${ }^{41}$ mantenía precisamente la idea de asimilar a los moriscos por el camino de abrirles los primeros escalones de los honores y cargos públicos. Entre aquéllos era ya una queja histórica, formulada en 1566 ante la Audiencia granadina por Francisco Núñez Muley ${ }^{42}$, la ingratitud de la monarquía hacia

${ }^{41}$ Hombres como Pedro de Valencia, Cellorigo, Pérez de Herrera, Mateo Alemán, Cervantes y los eclesiásticos y memorialistas que hasta el último instante permanecieron opuestos a la expulsión y favorables a los medios de asimilación pacífica. Datos diversos en F. MÁRQUEZ VIllanUEVA, "El morisco Ricote o la hispana razón de estado", Personajes y temas del Quijote, Madrid, 1975, pp. 304-317.

42 “. . . pies probados a los naturales deste rreyno y su lealtad a la corona Real en el tienpo de las comunidades, vuestra señoria hallara que en todos los Reynos y provinçias de castilla y andaluzia levantaron contra su Rey; y en este rreyno no tuvo en el ninguna alteraçion contra el serviçio de su alteza". Algunos moriscos granadinos, prosigue Núñez Muley, incluso tomaron armas y combatieron a favor del poder legal (R. FOULCHE DELBOSC, "Memoria de Francisco Núñez Muley", $R H, 6,1899$, p. 219). 
unos súbditos que fueron casi los únicos en permanecer monolíticamente fieles cuando la contienda de las Comunidades. El ejemplo político de Abdaláziz hubiera con seguridad evitado defecciones como la del morisco valenciano que fue amo de Marcos de Obregón en Berbería ${ }^{43}$.

Las intenciones de Luna llegan, sin embargo hasta el extremo del detalle. Cuantos se han ocupado de êl hasta ahora ${ }^{44}$ muéstranse maravillados por sus anotaciones marginales de vocablos arábigos en el texto "traducido". Es una técnica de humanista y de cuyo uso irresponsable le daba también ejemplo su inesperado mentor, fray Antonio de Guevara ${ }^{45}$. Luna mismo explica, satisfecho, su aparente chiquillada de "acotar como acoté al margen los mismos vocablos Aráuigos, que eran difficultosos, para que los lectores que supiesen esta lengua, puedan ver y gozar si están bien traduzidos y declarados, o no" (I, fol. 2v). En el día los únicos capaces de tal cosa son, por supuesto, sus hermanos moriscos. Dada la enemiga oficial hacia una lengua perseguida hasta el exterminio de sus manifestaciones más exiguas, se comprende bien la emoción de ese "gozar" la migaja de algún que otro vocablo infiltrado y objeto de los mismos honores que se tributan a la lexicografía grecolatina. Ultima línea de defensa de una lengua que Núñez Muley ${ }^{4}$ trataba de dignificar con

${ }^{43}$ Véase el excelente estudio de A. G. MONTORO, "Libertad cristiana»: relectura de Marcos de Obregón" $M L N, 91$ (1976), 213-230.

44 "Como muestra de la fidelidad de la versión, saca al margen los vocablos arábigos menos usuales de que el autor se sirve" (GODOY ALCÁNTARA, Historia crítica, p. 9). "Y para abonar el aserto se adornan las márgenes con citas de las palabras del original; pero el autor no cayó en la cuenta de que ponía algunas de uso moderno y desconocido en el siglo VIII, como mahzen por "palacio» (E. DE SAAVEDRA, Estudio sobre la invasión de los árabes en España, Madrid, 1892, p. 60). "Y el intérprete granadino registra al margen de su fingida traducción, para darle aires de más auténtica, multitud de vocablos arábigos, como si fuesen los empleados por el original". (MENÉNDEZ PIDAL, Floresta, t. 2, p. 49). "The author takes great pains to give his work the appearance of an authentic translation, even going to the extreme of filling the margin with pseudo-erudite footnotes wich make a pretense at discussing the correct translation of Arabic terms purportedly found in the original" (MONROE, Islam and the Arabs in Spanish scholarship, p. 9).

${ }^{45}$ Así en su anotación de los aracaísmos del fuero de Badajoz (Epístolas familiares, t. 1, p. 149 ss.) o de las ordenanzas de Toro (ibid., p. 273 ss.). Sólo que con miras festivas muy alejadas de las de Luna, Guevara finge o "falsifica" también sus apostillas, conforme al modelo "Jubenco es ternera".

46 "Memoria de Francisco Núñez Muley", p. 232. Sobre la decisiva importancia concedida por unos y otros a la cuestión de la lengua arábiga, L. CARDAILlAC, Morisques et chrétiens. Un affrontement polémique, Paris, 1977, 
el recuerdo de que ella tienen los Evangelios, los cristianos de la casa santa de Jerusalén y es vernácula para los cristianos hijosdalgos de la isla de Malta.

\section{Plano RELIGIOSO}

Lo mismo que el problema morisco empezaba y terminaba en un terreno religioso, la obra de Luna puede considerarse como un decisivo caminar hacia el enjuiciamiento polémico de dicho aspecto. Para Luna hay, en primer término, un encuadre inicial determinado por dos inconmovibles hechos históricos: la situación del cristianismo godo es tan lamentable bajo Rodrigo como pujante el Islam bajo el sabio Miramamolín Almançor. Después, el statu quo de los vencedores respeta la libertad religiosa de los vencidos. Como resultado, la España musulmana desconoce por completo un problema como el planteado a la monarquía católica de su tiempo.

Pero existe, además, una fenomenología del hecho religioso que Luna, no en vano devoto del "Philósopho esperimentador" (I, fol. 89r), refleja escrupulosamente. En primer lugar, los seres humanos, tienden en conjunto a posponer las cuestiones de fe ante las de interés personal, lo cual crea en todas las épocas un inevitable trasiego de conversiones o apostasías (según quiera mirarse). Una infanta de Arabia se hace cristiana por casar con Rodrigo, el obispo don Orpas islamiza para privar con los árabes, multitud de

pp-153-154. Contra la tradición luliana, característica de la baja Edad Media, el siglo XVI se niega a fomentar el estudio del árabe con miras a la predicación. Los intentos de fundar una cátedra en Valencia se estrellan contra un muro de antipatía y la mera posesión de alguna escritura arábiga constituirá delito ante el Santo Oficio (H. CH. LEA, The Moriscos of Spain: Their conversion and expulsion, London, 1901, p. 150). El apologista fray Jaime Bleda miraba con especial aversión tales intentos, que considera propios de sospechosos innovadores, "qui sordida lingua Morischorum cupiunt uti concionatores", pues en su opinión el árabe no merece la pena de aprenderse sino es "propter mysteria Veneris, quae in ea passim se offerunt" (Defensio fidei, Valencia, Juan Crisóstomo Garriz, 1610, p. 220). Con toda puntualidad, los libros plúmbeos presentaban la Palabra Divina a través del árabe y uno de aquéllos (Historia de la certidumbre del Santo Evangelio) contenía un elogio en regla de las bellezas de la lengua arábiga (GODOY AlCÁnTARA, Historia crítica, p. 60 ). Lo eficaz de la campaña contra cualquier escritura arábiga se manifiesta bien en los miserables restos de códices que en 1582 se hallaban en poder de la Inquisición granadina (C. RON DE LA BASTIDA, "Manuscritos árabes de la Inquisición granadina”, AlAn, 23, 1958, pp. 210-213). 
españolas lo hacen también para poder casarse con los vencedores. Las excepciones a la regla están vistas con cierta sospecha y más bien acarrean luctuosos desenlaces. La reina esposa de Rodrigo es capturada en Córdoba, sin que ni ella ni los suyos sean objeto de ninguna coacción o malos tratos. Se enamora después de la misma el infante Mahometo Gilhair, pero, contra lo que sería de esperar, rehúsa ella volver a su antigua ley e impone el cristianismo como condición para un matrimonio que es preciso mantener secreto, pues el momento "era muy duro e indecente para aquel hecho" (I, fol. 26r). Descubiertos, los cónyuges son llevados ante la iglesia mayor y requeridos por tres veces a volver a su primera fe. La negativa es causa de que sean descabezados con expreso consentimiento del padre del infante, que era rey de Túnez. No hay ulterior comentario, pero la conducta de ella parece más insensata que edificante y el destino final de ambos se perfila como inevicable respuesta a una provocación. La discretísima Egilona sólo pidió a Abdaláziz garantía de dejarla en su ley, antes de acceder al matrimonio (polígamo por parte de él).

Se comprueba cómo los "árabes" (Luna no gusta demasiado del gentilicio moros) se sirven de renegados en todos los terrenos (político, militar, económico) y recompensan adecuadamente sus méritos y trabajos. No hay problemas de casta o de honra ligados a la sangre. La conversión al Islam (buscada, pero no impuesta por los vencedores) confiere plena igualdad y abre todas las oportunidades. A las cristianas que reniegan para casarse se les otorga "gozar de las mismas preeminencias que ellos gozauan, y lo mismo los varones, ofreciéndoles otras libertades y repartimientos de tierras" (I, fol. 39r).

Pero, sobre todo, ni la conquista de España por los árabes ni la reconquista de los cristianos revisten el menor aspecto de cruzada o guerra religiosa. Luna remacha este punto esencial en el texto de la carta de don Pelayo a Tárif, concebida como una solemne declaración de guerra: “... aunque tienes ocupado nuestro Reyno de España con mal título y fuerça de armas, tenemos confiança en Dios que con su ayuda lo bolueremos a restaurar, y esta es nuestra intención, y no la que tú pretendes" (I, fol. $40 \mathrm{v})$. En aplicación de esta doctrina don Pelayo toma primero la pequeña ciudad de Canges y después la de Legio, que era "suya de derecho" (I, fol. 109v). Luna, cuyo confesado propósito "no fue más que memorar la verdad con rectitud y simplicidad, dándole ánima con no acostarse con afición a ninguna de las partes" (I, fol. 2r), se zafa del planteamiento religioso invocando la tesis "mudéjar" de la Reconquista como simple proceso de en- 
derezar una usurpación históricamente inaceptable ${ }^{47}$. Bajo dicha tesis, los motivos de contienda habrían terminado, en forma obvia, con la incorporación territorial del reino granadino. La idea de los peores adversarios de los moriscos, consagrada por la expulsión de 1609-1610, era que la Reconquista no había terminado mientras un solo musulmán habitara en suelo español, y por la cual correspondería tal honor no a Fernando e Isabel, sino al rey Felipe Hermenegildo ${ }^{48}$.

Luna desea también pasar juicios directos en un terreno religioso y puede hacerlo gracias a la coartada anacrónica de su Tárif Abentarique. Éste se apresura a manifestar su respeto hacia Jesús y la Virgen María como terreno de entendimiento inicial entre ambas leyes, pero acoge también las razones doctrinales de su incompatibilidad, determinada en no pequeña parte por el culto a las imágenes ${ }^{49}$, mencionado siempre con un matiz de escándalo. Los godos "adoran al benditíssimo IESU, hijo de la Virgen María, por su Dios y Criador, y adoran su imagen viuo y muerto en una Cruz crucificado" (II, fol. 33v). La corrupción introducida por Rodrigo (especialmente el amancebamiento de los clérigos) ${ }^{50}$ sólo

${ }^{47}$ La idea de que los cristianos luchan por la rectificación de un inaceptable estado de hecho surge ya en el siglo IX con la Crónica Albeldense. Su más brillante formulación se debe a don Juan Manuel en el Libro de los estados: "Et por esto a guerra entre los christianos et los moros, et abrá fasta que ayan cobrado los christianos las tierras que los moros les tienen forçadas; ca, quanto por la ley nin por la secta que ellos tienen, non avría guerra entre ellos. Ca Jhesu Christo nunca mandó que matasen nin apremiasen a ninguno por que tomasen la su ley, ca Él non quiere serviçio forçado sinon elque se faze de buen talante et de grado" (ed. R. B. Tate y I. R. Macpherson, Oxford, 1974 , p. 53). La vigencia y características de dicha idea son estudiadas por $R$. MENÉNDeZ PidAl, La España del Cid, Madrid, 1929, t. 2, p. 675, y D. CATALÁN MENÉNDEZ PIDAL, "Ideales moriscos en una crónica de 1344", en su apartado "Cruzada y Reconquista" (p. 580-582).

${ }^{48}$ Así gustaban de llamarlo a principios de su reinado los entusiastas del goticismo (por ejemplo, Lope en la dedicatoria de La hermosura de Angélica en 1602).

${ }^{49}$ Sobre el tema de las imágenes en la literatura polémica, L. CAR. DAILlac, Morisques et Chrétiens, pp. 330 ss. Luna presenta la adoración de las imágenes como el foco de la religión cristiana y también a modo de una práctica en sí aborrecible: "Trata como el Infante Mahometo Gilhair trato amores con la Reyna muger del Rey don Rodrigo, y como se torno Christiano, y adoraua las imágenes en secreto, y como por ello fue degollado por mandado de su padre" (I, cap. XI).

${ }^{50}$ Sobre el escándalo morisco ante la inmoralidad del clero cristiano, L. CARDAILlAC, $o p$. cit, pp. 333 ss. Con la poligamia islámica in mente, Luna presenta a su Tárif maravillado ante la promiscuidad incontrolada de los sacerdotes; "Tienen sus Clérigos y religiosos, andan vestidos con ropas de fina 
ha dejado un corto número de creyentes virtuosos, "y estos tales son gente que tratan verdad unos con otros, y mantienen la fe y palabra que prometen entre ellos y hacen obras de caridad" (II, fol. 34r). En lo que suena a inversión de un famoso juicio de fray Hernando de Talavera ${ }^{51}$, estos buenos cristianos tienen virtudes morales "que no les hazen ventaja nuestros Árabes en este particular" (II, fol. 34v). Pero la mayor parte son viciosos, mal inclinados y beben demasiado vino. El tono de la sociedad cristiana es desagradable e indigno ${ }^{52}$ : "Mas los que son viciosos entre ellos (que son la mayor parte) tienen malas costumbres, y usan de muchas injusticias y traiciones unos contra otros, que viuen en mucho trabajo y desuentura" (II, fol. 34r).

Los lectores de la Verdadera historia tendrán también ocasión de aprender de primera mano acerca del Islam, comenzan-

lana, bien largas. No pueden ser casados, aunque el Rey don Rodrigo les dio licencia para tener mugeres, una dos y tres, y las demas mancebas que quisiessen contra su misma ley, y también a los populares: y los que han sido dellos mal inclinados y viciosos usaron tanto desta liberalidad, que podre afirmar con verdad que ay de presente en este Reyno mas hijos aspurios y de malos ayuntamientos, que ligitimos" (II, fol. 33v).

${ }^{51}$ Según una relación contemporánea, el primer arzobispo de Granada "holgaba mucho de andar entre esta gente $i$ alabava mucho su pobreza con tanto contentamiento, i mucho su humildad, i mucho su obediençia; alabava mucho sus costumbres, dezía que ellos avían de tomar nuestra fe y nosotros sus costumbres, i que tovieran o toviesen fe hazen en las costumbres a los xriptianos mucha ventaja" (F. MárQUEZ VILLANUEVA, Investigaciones sobre Juan Álvarez Gato, Madrid, 1960, p. 117, nota).

${ }^{52}$ Luna se queja así del oneroso vivir entre esta masa y sociedad de "aspurios". Es preciso ver en ello una variante temática de la insatisfacción morisca con la realidad cotidiana de la vida española. El 4 de noviembre de 1609 (unas semanas después de la expulsión valenciana) Luna escribía de pésimo humor al arzobispo Vaca de Castro: "Y estoy harto de las cosas de España, porque se vive en ella con mucho trabajo y cada día va empeorando" (D. CABANELAS, "Cartas del morisco granadino Miguel de Luna", p. 38). Alonso del Castillo escribió también, a su vez, un poema arábigo en que contrasta la hermosura de Granada con su pueblo rebosante de envidias, rencores y soberbias (D. CABANELAS, "El morisco Alonso del Castillo y unos versos sobre Granada", Miscelánea al profesor Antonio Marín Ocete, Granada, 1974, t. 1, pp. 79-85). El memorial conspiratorio que ciertos moriscos aragoneses escribían a Enrique IV de Francia en 1602 no es en esto menos explícito: "CarI'Espagne est épuisée, et plus mal gouvernée de jour en jour" (Mémoires authentiques de Jacques Nompar de Caumont, duc de la Force, Paris, 1843, t. 1, p. 345). Se autodescriben estos moriscos como "mores de nation" y de los más antiguos del mundo, pues viven en España desde su conquista por el rey Muley Jacop Al-Mançor (sic, p. 341). Quiere decir, por tanto, que habían leído y dado crédito a la Verdadera historia. Miguel de Luna podía estar sa. tisfecho. 
do por aquello de que Dios "predestina a quien es seruido por su grande misericordia" (I, fol. 4v). Luna no ha hecho, sin embargo, las paces con un fatalismo a ultranza ${ }^{53}$, que trata de reconciliar de algún modo con los dogmas cristianos. Entre los epitafios ascéticos de Iacob Almançor, se lee: "Mira que te compró con alto precio, y te dio priuilegio para saluarte usando del libre aluedrío, como él manda" (II, fol. 29v). Una nota marginal enrevesa aquí, más que aclara, tal atrevimiento: "Si creyeran los Moros ser este alto precio la sangre de N. Redemptor, como en effecto de verdad lo es, serían dichosos. Mas ellos dizen ser la creencia y penitencia, y ésta aunque la hazen regurosa es para su mayor condenación" (II, fol. 29r). Y poco más abajo el principio de Islam, ya involucrado con el de predestinación (tan familiar para los oídos cristianos de la época), se confunde aún más al dar paso a un punto doctrinal de fuerte sabor calvinista ${ }^{54}$ : "Mira que la miseria y pobreza no es falta de los padres ni parientes, ni de los bienes temporales, sino el carecer de la amistad de Dios y de su bienaventurança" (II, fol. 29v).

Luna no ilustra el caso, fácil de entender y de hallar entre los suyos, de un indeciso entre ambas religiones. Actuaba en él, además, una fuerte inclinación racionalista. Sin duda le eran familiares las ideas extremas de Maquiavelo y Tácito, más divulgadas de lo que se ha creído en la España de su tiempo y características de los que llamaban "políticos" escándalo, cierto usuŕpador árabe no se priva de proclamar a Maquiavelo en una especie de versión islámica:

... entre los hombres en el derecho natural no auia sucession para reynar, porque todos los Reyes de la tierra eran tiranos, y que tan solamente pertenecia el ceptro Real al que Dios le daua esfuerço y sabiduria para poder regir y gouernar, y no a otro ninguno (I, fol. 59r).

Luna rechazaba como irracionales, de acuerdo con la apologética musulmana, algunos artículos básicos del dogma cris-

${ }^{53}$ De un modo similar, el Mancebo de Arévalo condenaba el fatalismo y los horóscopos (E. DE SAAVEDRA Y MORAGAS, "Escritos de los moriscos sometidos al dominio cristiano", Memorias de la Real Academia Española, 6, 1899, pp.152-153).

${ }^{54}$ Los moriscos se interesaban en el protestantismo (que al menos no veneraba las imágenes) y estaban informados acerca de sus principales doctrinas. Como observa L. Cardaillac, los lugares de máxima penetración de libros protestantes en España coinciden con las provincias de mayor densidad morisca, op. cit., p. 129).

${ }^{55}$ F. MÁRQUEZ VillanUeVA, "El morisco Ricote o la hispana razón de estado", pp. 317-329. 
tiano. Lo desliza con suma habilidad al impugnar la creencia de que las yeguas de Vandaluzía puedan quedar preñadas del viento: "Aunque esta opinión para mí es falsa, y de hombres que saben poca Philosophía natural, porque ninguna yegua, ni otro animal viuiente puede engendrar sin cópula de macho de su especie" (II, fol. 34v). De aquí toma pie para un duro ataque contra "la ficción que los Philosophos [léase teólogos] de aquel Reino fingen contra la naturaleza, y el concierto y buena orden de las causas naturales que nuestro soberano Dios ordenó para la conseruación de las especies individuales" (II, fol. 34v). Luna rechaza con "argumento científico" toda posibilidad de concepción virginal como forma de socavar, por consiguiente, la Encarnación y naturaleza divina de Jesucristo, punto de irreductible discrepancia entre ambas leyes ${ }^{56}$. Puede haber controversia acer ca de qué clase de musulmán pudiera ser Miguel de Luna. Cabe estar seguros de que no era cristiano ${ }^{57}$.

El profeta Mahoma no es mencionado una sola vez en todo el libro. Se elude así el tener que acompañar su nombre de los epítetos insultantes que en este punto vinieron a ser obligados, y

${ }^{56}$ L. Cardaillac, op., cit., p. 260 ss. En un plano de mayor responsabilidad filosófica, L. MASSIGNON, "Le Christ dans les évangiles selon Ghazali" Revue des Études Islamiques, 6 (1932), 523-536. Luna sorprende en todo esto por rechazar, como se ha visto, la creencia del nacimiento virginal, mantenida también por la ortodoxia islámica. Maquiavelo y Tácito, el vetusto averroísmo médico y las jóvenes corrientes científicas parecen haber confluido en él para moldear un sólido racionalista. Otro médico heterodoxo, Francisco López de Úbeda, atacaba la misma doctrina con las chanzas de su Pícara Justina, nada dispuesta a reclamar nacimiento de "virgen incorrupta" como Rómulo, Platón y otras ilustres personas (ed. J. Puyol, Madrid, 1912, I, p. 76).

${ }^{57}$ En la estimación de Godoy Alcántara tanto Alonso del Castillo como Miguel de Luna no tuvieron "más que el barniz de cristianos", y este último destacaría por su temerario desenfado proislámico y por su escasa formación teológica (Historia crítica, pp. 104-105). Lo mismo piensa también D. Cabanelas, que recuerda las aficiones de Luna a urdir supercherías y ciertos roces que sus atrevimientos le causaron con la Inquisición, en circunstancias que no especifica (El morisco granadino Alonso del Castillo, p. 23), todo ello más que bastante para atribuirle la parte más filoislámica de los libros del Sacromonte. Hubo quienes, años después de su muerte, lo consideraban sospechoso en la fe, razón por la cual el arzobispo Pedro de Castro había de defender su cristiana memoria en 1618: "El Miguel de Luna era hombre de bien, de habilidad e ingenio. Vivió católicamente; murió con todos los sacramentos en casa del secretario Alonso de Valdivia, en un lugar suyo. Tuvo a cargo su hacienda y dio buena cuenta de su administraçión: Euge serve bone, etc. Y Su Majestad le hizo merçed como criado suyo y su intérprete de la lengua árabe, y está admitido para hijodalgo en procesos suyos de Granada y como tal goçaba de las libertades de los hijosdalgos y que no fuese presa su persona" (ibid., p. 15). 
el mejor de los cuales era "sucio". Además, se afirmaba con ello de paso que el profeta no era lo esencial del islamismo y podía ser relegado al capítulo de adiaphora.

Los judíos, por último, no constituyen ningún problema especial. Guardan la ley de Moisés, "aunque depravada por ellos" (II, fol. 34v), de acuerdo con lo establecido en ambas ortodoxias.

\section{MIGIEL DE LENAO LA CRIPTOHISTORLA}

El extraño modus operandi de Miguel de Luna, su irresponsable hurtarse a la tradición, desconcertaba como sabemos a Menéndez Pidal. Sin poder hacer pies ni cabeza de tanto infundio, se lanzaba a un juicio extremado acerca de la misma salud mental del intérprete de arábigo: "Todo falsario tiene un poco de perturbado, pero Luna tiene un mucho; sus invenciones aturden y marean al lector, como las de un loco, pues desquician y contradicen sin finalidad ni fundamento todo cuanto por tradición estamos habituados a tener por cosa sabida" (pp. 49-50). Pero todo es un gran error. Sin dotes poéticas y dueño de una cultura muy limitada, Luna impresiona, al contrario, por la viveza en crudo de su ingenio. No sólo no anduvo esta vez afortunado don Ramón, sino que su tropiezo es inexcusable tras las páginas clarividentes de Godoy Alcántara sobre la obra de Luna. Paga así por una desatención a las realidades del problema morisco que, en rigor, no es sólo suya, sino la de una historiografía decimonónica cuyo nacionalismo "liberal" continuó, en esencia, los planteamientos de los apologistas a sueldo del duque de Lerma.

Frente a este giro en falso del problema han venido a alzarse después los juicios tajantes de distinguidos arabistas. L. P. Harvey ve a Luna empeñado con todo intento en un proyecto mitificador afín al de los plomos del Sacromonte ${ }^{58}$ J. T. Monroe advierte el carácter polémico de la faramalla histórica de Luna y su orientarse hacia una apología de la tolerancia que obliga a alinearlo, para efectos prácticos, junto a la novela morisca ${ }^{59}$. La correspondencia es aquí exacta, y en ella se funden íntimamente Literatura e Historia. Las páginas de Luna no luchan en vacío, y si al principio dan esa impresión es efecto calculado para que se busque en ellas la otra mitad no escrita (porque no podía escribirse). Con el mismo proceder, la novela morisca aludía a la rea-

${ }^{58}$ The Moriscos and "Don Quixote", Inaugural Lecture, London, 1974.

${ }^{59}$ Islam and the Arabs in Spanish scholarship, p. 11. 
lidad contemporánea mediante un sistema de contradicciones silenciosas ${ }^{60}$. Aquella consideración de Luna como un perturbado es gemela del rutinario encomio del género morisco cual lindas "novelitas", escritas con "pluma de ángel" para el más beato de los entretenimientos ${ }^{61}$.

El mensaje, nunca explícito, pero omnipresente en la $V e r d a$ dera historia se comunica en diversos niveles. Los árabes vienen a la Península no sólo como judicium $D e i^{62}$ por los pecados de Rodrigo (tesis de la historiografía cristiana), sino también como alternativa providencial y rectificadora de la corrupción visigoda. Los árabes representan una superioridad moral que, basada sobre todo en el respeto de los pactos, conduce a una razonable libertad de conciencia. La lección de la historia es la posibilidad de un convivir ordenado bajo el principio "mudéjar" y no hay motivos de orden jurídico ni religioso para pasar una cuenta histórica a los descendientes, esto es, a los moriscos que menciona una sola vez ${ }^{63}$. Hay después un plano apologético: la fe islámica no es diabólica, bárbara ni inmoral, mientras que el cristianismo no está a cubierto de objeciones racionalés ni menos aún puede acreditarse con un cuadro de perfección ética. Moros y cristianos de buena voluntad pueden entenderse en paz y hasta en guerra (cierta clase de guerra), tienen nociones religiosas comunes y el gran estadista de la España musulmana se llama, al fin y el cabo, Iacob, es decir, Santiago ${ }^{64}$. Limpieza de sangre, odio casticista,

${ }^{60}$ C. GUILlÉN, "Literature as historical contradiction: El Abencerraje, the Moorish novel, and the eclogue", Literature as system, Princeton, 1971, p. 178. Reflexiones confluyentes sobre la historicidad de la novela morisca y los problemas de casta del siglo XVI español en G. A. SHIPLEY, "La obra literaria como monumento histórico:el caso del El Abencerraje", JHPh,2 (1978), 103-120.

${ }^{61}$ Se impone citar aquí, como ejemplo de una crítica beatificante vuelta de espaldas a toda realidad, la ya citada obra de L. MORALES OLIVER, La novela morisca de tema granadino.

${ }^{62}$ L. A. GARCÍA MORENO, El fin del reino visigodo de Toledo, Madrid, 1975 , p. 26.

${ }^{63}$ Iacob Almançor era especialmente riguroso en castigar el robo en yermo o en poblado. "Esta costumbre usaron hasta nuestros tiempos los Moriscos del Reino de Granada y entre ellos casi la tenían conuertida en naturaleza", apostilla Luna (II, fol. 9). Respondía así al clamor contra el bandidaje morisco, fenómeno endémico y revestido de un carácter semipolítico en tierras de Granada, como estudian A. DOMÍNGUEZ ORTIZ y B. VINCENT, Historia de los moriscos. Vida y tragedia de una minoría, Madrid, 1978, pp. 144-145.

${ }^{64} \mathrm{La}$ intención de Luna llega en esto casi a un despunte irónico al tratar largamente de cierto príncipe de Arabia, hijo del califa Abilgualit, llamado indistintamente Iacob y Iacobo. Lo llamaron tal en el acto solemne de su jira: 
sentido social de la honra, vizcainía, goticismo antisemita, quedan expuestos como una tabla de crasos mitos y prejuicios. Finalmente, una disidencia programática: la eventual rectificación basada en trabajo, ciencia, comercio, antipauperismo y libertad de conciencia, en alianza virtual con el proyecto de los políticos y arbitristas judeo-conversos ${ }^{65}$. Tan radical cambio de rumbo sería el equivalente moderno del alejar de España la pesadilla de Rodrigo (de hecho mediante una nueva semitización, con los conversos como cabeza y los moriscos como brazos). Porque la analogía de la España gótica del rey forzador con la neogótica del soberano austero (mas "forzador" en otro sentido) es abrumadora y cíclica en el libro de Luna.

No es casualidad que la Verdadera historia sólo se imprimiera con anterioridad a 1609 en Granada, Zaragoza y Valencia ${ }^{66}$, focos de máxima preocupación sobre el futuro de los moriscos, tan decisivo para aquellos reinos. Los tagarinos, como se ha visto, la leyeron con avidez. Porque lejos de "falsificar", Luna trae, por el contrario, un aire de autenticidad a la discusión del problema morisco, en torno al cual era claro que iba pronto a darse una vuelta irremediable del ser de España. Vuelta que hoy sabemos fue timoneada por el duque de Lerma, pero que pudo haber sido también (pues allí estaban las ideas y los hombres) por gentes como Pérez de Herrera, Cellorigo o Pedro de Valencia, por no decir Miguel de Luna. Escribía éste "verdadera historia", pero no la del siglo VIII, sino la de su tiempo. Y siendo un disidente criptoislámico no tenía otra alternativa que la de hacerla pasar como crip-

“. . .quiere y es su voluntad que sea jurado por vosotros el Principe y señor nuestro Iacobo Almançor su hijo legitimo" (I, fol, 69 v). Por extraño que parezca, algu. nos moriscos veneraban también a Santiago, llevados de una identificación de los Apóstoles con los compañeros del Profeta, y dentro de la cual atribuían al Hijo del Trueno las hazañas de 'Ali' (CARDAILlaC, op. cit., p. 33).

${ }^{65}$ Sobre el espíritu económico de signo europeo implantado por los moriscos expulsos en Túnez, D. BRAHIMI, "Quelques jugements sur les maures andalous dans les régences turques au XVIr siècle", Recueil d'études sur les moriscos andalous en Tunisie, Madrid, 1973, 135-149. Por la misma lógica, el poeta valenciano Gaspar de Aguilar celebra en su poema Expulsión de los moros de España (Valencia, 1610), cómo España habrá de volver ahora a la beatitud de la Edad de Oro, en que no había más riquezas que la labranza y el ganado.

${ }^{66}$ Con un total de cuatro ediciones: Granada 1592 y 1600, Zaragoza 16021603 y Valencia 1606. La posterior boga editorial de Luna en la segunda mitad del siglo XVII, así como el éxito de sus traducciones, han de verse, en cambio, como un interés popular en la novelización histórica y en la curiosidad por los temas orientales, que no hallaba fuentes mejores en que satisfacerse. 
tohistoria. Tal ha sido, por un lado o por otro, casi toda la novela española del siglo XVI.

Cierto que nuestro morisco y su enrevesada estrategia hacían pagar un terrible precio a la Historia, reducida a mero estribo de una voluntad de leyenda. Pero en este pecado no se hallaba tan solo, pues dicha transgresión era frecuente dentro y fuera de España, en contextos de lucha ideológic $a^{67}$. No contaba en ello sino el tener una buena causa que defender, y la de Luna era eminentemente digna, además de acorralada. Como se ha visto, Luna aprendía de un obispo (aunque tampoco cristiano viejo) ${ }^{68}$ a servirse de la Historia para pasar un contrabando literario. En el otro extremo, Quevedo esgrimía más desaforado aún que Luna en favor de Santiago Matamoros y de tantas otras cosas para él entrañables, sin mirar a que fuesen verdad o mentira (porque no se trataba de eso). Y le contradijo, como había de ser y con la única lógica antihistórica que de veras contaba, un carmelita de origen morisco ${ }^{69}$.

El intérprete Miguel de Luna no estaba interesado más que en hacer oír la voz del morisco en lucha por su dignidad humana y aun por su existencia física. Su voluntad de leyenda responde a la cerrazón de la España oficial ante todo asomo no ya de disidencia, sino de simple diversidad ideológica. Técnicamente, las ideas de Luna sobre los árabes no son más falsas que las del goticismo exacerbado de su época, y ni aun el P. Mariana se libró de las fábulas de don Rodrigo y la Cava. El espíritu polémico no es que saltara en ocasiones al palenque de los estudios históricos (como ocurría y hasta ocurre en todas partes), sino que lo polarizaba, invadido por una ortodoxia político-religiosa que lo sustrajo a su propia naturaleza. La conciencia cristiano-vieja lo mudó de saber en creencia y, armada hasta los dientes, pudo imponerle como quiso su propia voluntad de leyenda. Nicolás Antonio (un contemporáneo de Mabillon) fue eficazmente silenciado por el Santo Oficio ${ }^{70}$, defensor del monumento de vanidad de los falsos cronicones.

${ }^{67}$ Véase el luminoso estudio de R. LIDA, "Sobre Quevedo y su voluntad de leyenda", $F i l$, 8 (1962), 273-306.

${ }^{68} \mathrm{Su}$ costado de converso más que sospechoso ha sido puesto en claro por $\mathrm{A}$. REDONDO, Antonio de Guevara et l'Espagne de son temps, Genève, 1976, p. 54.

${ }^{69}$ Fray Gaspar León de Tapia, que llamaba San Trago al Apóstol (L. RUBio, "En torno a España en su historia de Américo Castro", RLit, 5, 1954, p. 297).

${ }^{70}$ Véase la correspondencia ahora publicada por R. JAMMES y O. GORSSE, "Nicolás Antonio et le combat pour la verité (31 lettres de Nicolás Antonio à Vázquez Siruela)", HNS, 411-428. La Censura de historias fabulosas (origi- 
La Historia en cuanto tarea intelectual había de ser, sin escapatoria posible, una de las primeras víctimas del aire enrarecido de aquella república de hombres encantados. Y ni siquiera acaba aquí este laberíntico deambular entre espejos múltiples, porque, tras una morada de siglos, los fantasmas toman el regusto del caserón y se vuelven duros de exorcizar. El problema de los moriscos es ejemplo egregio de cómo España vino a ser un país "heredohistórico", además de "víctima de una propaganda política iniciada en pleno siglo XVI" derna historiografia, no hay grandes prisas por reconocer cuanto difiera de los puntos de vista oficiales de 1610. Lo mismo que Pedro de Valencia, inédito ${ }^{72}$, continúa siendo una nota a pie de página, Miguel de Luna hace mucho que debiera de haber alcanzado otra fama que la de "falsario", con añadiduras de "perturbado" y de "ebrio".

Francisco Márquez VillanUeva

Harvard University.

nalmente Triunfo de la verdad) no pudo publicarse hasta 1747 , y aun entonces solo tras denodados esfuerzos de Mayáns y Siscar.

${ }^{71}$ M. Azaña, Memorias políticas y de guerra, Madrid, 1976, t. 3, p. 467.

${ }^{72} \mathrm{Su}$ informes al confesor de Felipe III fray Diego de Mardones Acerca de los moriscos de España solo es conocido a través de los resúmenes de $M$. Serrano y Sanz, "Pedro de Valencia, Estudio biográfico y crítico", $R A B M, 3$ (1899), 290-312, y de C. ColonGE, "Reflets littéraires de la question morisque entre la guerre des Alpujarras et l'expulsion", Boletín de la Academia de Buenas Letras de Barcelona, 33 (1969-1970), 137-243. 